\title{
Modelling study of the impact of deep convection on the utls air composition - Part I: Analysis of ozone precursors
}

\author{
V. Marécal ${ }^{1}$, E. D. Rivière ${ }^{1,{ }^{*}}$, G. Held ${ }^{2}$, S. Cautenet ${ }^{3}$, and S. Freitas ${ }^{4}$ \\ ${ }^{1}$ Laboratoire de Physique et Chimie de l'Environnement/CNRS and Université d'Orléans, 3A Avenue de la Recherche \\ Scientifique, 45071 Orléans cedex 2, France \\ ${ }^{2}$ Instituto de Pesquisas Meteorológicas, Universidade Estadual Paulista, CX Postal 281 17033-360 Bauru, S.P., Brazil \\ ${ }^{3}$ Laboratoire de Météorologie Physique/CNRS-OPGC/Université Blaise Pascal, 24 Avenue des Landais, 63177 Aubière \\ cedex, France \\ ${ }^{4}$ Centro de Previsão de Tempo e Estudos Climàticos, Rodovia Presidente Dutra, km 40 SPRJ 12630-000, Cachoeira Paulista - \\ SP, Brazil \\ *now at: Groupe de Spectrométrie Moléculaire et Atmosphérique UMR 6089 and Université de Reims Champagne-Ardenne, \\ Faculté des Sciences, Bât. 6, case 36, BP 1039, 51687 Reims Cedex 2, France
}

Received: 10 November 2004 - Published in Atmos. Chem. Phys. Discuss.: 23 September 2005

Revised: 6 February 2006 - Accepted: 15 March 2006 - Published: 18 May 2006

\begin{abstract}
The aim of this work is to study the local impact on the upper troposphere/lower stratosphere air composition of an extreme deep convective system. For this purpose, we performed a simulation of a convective cluster composed of many individual deep convective cells that occurred near Bauru (Brazil). The simulation is performed using the 3-D mesoscale model RAMS coupled on-line with a chemistry model. The comparisons with meteorological measurements show that the model produces meteorological fields generally consistent with the observations.

The present paper (part I) is devoted to the analysis of the ozone precursors $\left(\mathrm{CO}, \mathrm{NO}_{\mathrm{x}}\right.$ and non-methane volatile organic compounds) and $\mathrm{HO}_{\mathrm{x}}$ in the UTLS. The simulation results show that the distribution of $\mathrm{CO}$ with altitude is closely related to the upward convective motions and consecutive outflow at the top of the convective cells leading to a bulge of $\mathrm{CO}$ between $7 \mathrm{~km}$ altitude and the tropopause (around $17 \mathrm{~km}$ altitude). The model results for $\mathrm{CO}$ are consistent with satellite-borne measurements at $700 \mathrm{hPa}$. The simulation also indicates enhanced amounts of $\mathrm{NO}_{\mathrm{x}}$ up to 2 ppbv in the $7-17 \mathrm{~km}$ altitude layer mainly produced by the lightning associated with the intense convective activity. For insoluble non-methane volatile organic compounds, the convective activity tends to significantly increase their amount in the 7$17 \mathrm{~km}$ layer by dynamical effects. During daytime in the presence of lightning $\mathrm{NO}_{\mathrm{x}}$, this bulge is largely reduced in the upper part of the layer for reactive species (e.g. isoprene, ethene) because of their reactions with $\mathrm{OH}$ that is increased
\end{abstract}

Correspondence to: V. Marécal

(vmarecal@cnrs-orleans.fr) on average during daytime. Lightning $\mathrm{NO}_{\mathrm{x}}$ also impacts on the oxydizing capacity of the upper troposphere by reducing on average $\mathrm{HO}_{\mathrm{x}}, \mathrm{HO}_{2}, \mathrm{H}_{2} \mathrm{O}_{2}$ and organic hydroperoxides. During the simulation time, the impact of convection on the air composition of the lower stratosphere is negligible for all ozone precursors although several of the simulated convective cells nearly reach the tropopause. There is no significant transport from the upper troposphere to the lower stratosphere, the isentropic barrier not being crossed by convection.

The impact of the increase of ozone precursors and $\mathrm{HO}_{\mathrm{x}}$ in the upper troposphere on the ozone budget in the LS is discussed in part II of this series of papers.

\section{Introduction}

Several studies based on observations (e.g., Dickerson et al., 1987; Thornton et al., 1997) and on model results (e.g., Pickering et al., 1990; Wang et al., 1996; Wang and Prinn, 2000; Barth et al., 2001; Mari et al. 2003; DeCaria et al., 2005) have shown that deep convection plays a major role in the vertical transport of chemical species from the lower troposphere to the upper troposphere. Tropical convection is of particular importance since the source of most stratospheric chemical species lies in the tropics (Holton et al., 1995) and any species entering the stratosphere may have an impact on the ozone budget. In the tropics, the surface emissions can be lifted rapidly via convective ascents either to the upper troposphere (UT) or to the lower stratosphere (LS). In most cases, the convection does not penetrate the cold point

Published by Copernicus GmbH on behalf of the European Geosciences Union. 
tropopause and the surface emissions only reach the tropical tropopause layer (TTL). Several definitions for the TTL have been proposed in the literature. We will retain hereafter the following: TTL is the transitional layer between air having tropospheric characteristics and air having stratospheric characteristics. The TTL extends from about $12-14 \mathrm{~km}$ to about $17-20 \mathrm{~km}$ altitude. From this layer, the air is then entering the stratosphere through slow radiative heating ascent. Therefore, the impact of the tropical deep convection on the redistribution of chemical species in the TTL is an important issue in the understanding of the stratospheric ozone budget at global scale.

Several modelling studies (e.g., Wang et al., 1996; Tulet et al., 2002 and Wang and Prinn, 2000) have shown that a deep convective event significantly redistributes all chemical species in the vertical. In particular, the convective updrafts lift rapidly the pollutants emitted at the surface up to the UT where they are horizontally spread by the convective outflow. Apart from its dynamical effect, convection also modifies the chemical budget of the troposphere in particular by scavenging soluble species and by aqueous chemistry (e.g., Mari et al. 2000; Yin et al. 2001; Wang and Prinn, 2000; Barth et al. 2001). Since the modelling of these processes is fairly complex, each of these studies focused on a particular aspect of the interaction between the microphysics and the chemistry. In particular, Mari et al. (2000) estimated quantitatively the scavenging efficiency in a deep convective event over Brazil for soluble species. In parallel, Barth et al. (2001) investigated the fate of tracers of varying solubilities when liquid hydrometeors are converted to ice and Wang and Prinn (2000) showed the importance of aqueous chemistry for a tropical maritime convective cloud in the total sulfate production. Another process affecting the air composition and related to deep convection is the production of $\mathrm{NO}_{\mathrm{x}}$ through lightning (e.g., Wang and Prinn, 2000; DeCaria et al., 2005). In particular, Wang and Prinn (2000) showed that the lightning $\mathrm{NO}_{\mathrm{x}}$ is very important in the $\mathrm{O}_{3}$ chemistry via chemistry and modification of UV fluxes. For its case study, DeCaria et al. (2005) found an ozone production of $10 \mathrm{ppbv}$ that can be attributed to lightning NO in the UT.

Although tropical regions are of major importance for stratospheric ozone, there have been only few field campaigns in the tropics documenting the tropical Upper Troposphere and Lower Stratosphere (UTLS). There is still a need for measurements of both tropospheric and stratospheric species in the whole altitude range of the tropical UTLS in the vicinity of convective events to improve our understanding of the impact of deep convection on the UTLS air composition. Nevertheless, the recent interest of the scientific community for the tropical UTLS has led to the design of a major field experiment in Brazil within the framework of the HIBISCUS (Impact of Tropical Convection on the Upper Troposphere and Lower Stratosphere at Global Scale), TroCCiNO $_{\mathrm{x}}$ (Tropical Convection, Cirrus and Nitrogen Oxides) and TroCCiBras (Tropical Convection and Cirrus ex- periment Brasil) projects. The scientific objective common to the three projects is to study the interaction between meteorological, atmospheric chemistry and lightning parameters in tropical convection between ground level and the lower stratosphere in Eastern Brazil and in particular in the Bauru region (State of São Paulo in Brazil). The main field campaign of these coordinated projects took place during February and March 2004. The present study was done within the frame of the preparation for this campaign.

Central and Eastern Brazil have already been in the past the scene of a few field campaigns during the wet season, providing airborne and balloon-borne measurements of trace gases and water vapour in the troposphere and in the LS. The main airborne experiments were the TROPOZ II (Tropospheric Ozone) experiment that took place in January 1991 (Marenco et al., 1995) and the TRACE A (Transport and Atmospheric Chemistry Near the Equator-Atlantic) experiment that took place during the dry (September/October) and the wet (April) seasons in 1992 (Fishman et al., 1996). In parallel, balloon-borne instruments were flown in Central and Eastern Brazil mainly performing measurements of ozone (Kirchhoff et al., 1996; Logan, 1999; Pundt et al., 2002; Vömel et al., 2002; Thompson et al., 2003). One of the most outstanding results from these observational studies was, that there is a large increase of the ozone mixing ratio with altitude starting in the UT well below the tropopause (Logan, 1999; Pundt et al., 2002; Thompson et al., 2003). The starting altitude for this ozone increase is located at the basis of the TTL and varies from about 13 to $16 \mathrm{~km}$. As for ozone precursors, an upper tropospheric maximum for $\mathrm{CO}$ mixing ratios was also found above $7 \mathrm{~km}$ altitude by Jonquières and Marenco (1998) from TROPOZ II airborne observations during the wet season. They showed that this maximum was related to the uplifting of surface emissions by convective processes. These studies and others (e.g., Vömel et al., 2002) show that the TTL is characterized by a specific air composition, in particular during the wet season.

The aim of the present study is to investigate the local impact of an extreme convective event on the UTLS air composition using a modelling approach. The selected case was observed during the 2001 HIBISCUS technical preparation campaign. It was a large and very severe convective storm that developed in the Bauru area on 8 February 2001 with a maximum intensity during the late afternoon causing floods. The particular interest of this system is that it is composed by a cluster of convective cells, many of them reaching the cold point tropopause, leading to a possible impact of convection on the LS air composition. Different types of convective systems exist in the tropics (organized or non-organized, maritime or continental). The type of system studied in the present paper is continental and non-organized. The impact of such a multi-cell convective event on the UTLS composition at the scale of the system has never been studied before. The present work is based on the use of the three-dimensional regional atmospheric model RAMS (Regional Atmospheric 


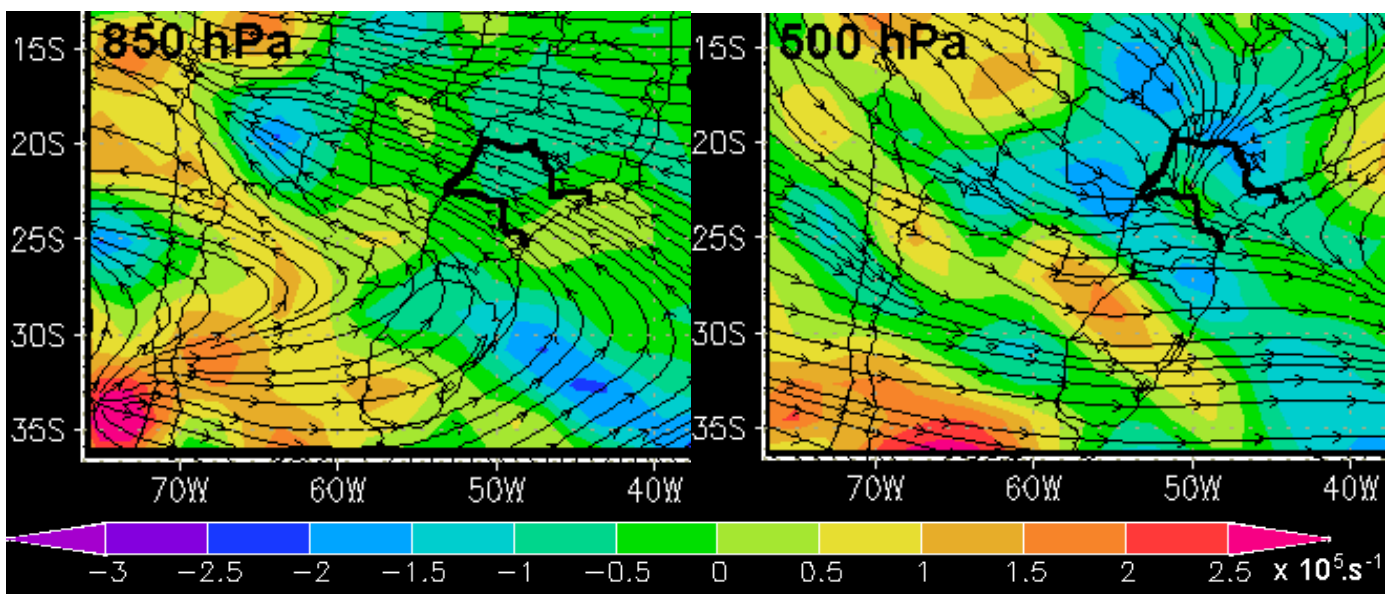

Fig. 1. 8 February 2001 at 00:00 UT: Streamflow lines and divergence (in s ${ }^{-1}$ ) at $850 \mathrm{hPa}$ (left panel) and $500 \mathrm{hPa}$ (right panel), with borders of the State of São Paulo shown in bold, from CPTEC Global analysis.

Modeling System) (Cotton et al., 2003) coupled with on-line chemistry and emission modules. This tool allows the quantification of the impact of vertical transport, the horizontal transport, as well as lightning $\mathrm{NO}_{\mathrm{x}}$, gaseous and aqueous chemistry on the air composition. The present paper is the first part of a series of two. It is mainly devoted to the analysis of the results for ozone precursors: $\mathrm{CO}, \mathrm{NO}_{\mathrm{x}}$ and nonmethane volatile organic compounds (NMVOC). The second part of the series (Rivière et al., 2006) studies ozone based on the results discussed in Part I. In Sect. 2 of the present paper, a description of the case study is given. Details on the model used to perform the simulation are given in Sect. 3 . The simulation results for the meteorological parameters are evaluated in Sect. 4. They are compared to the data collected by near-surface observational stations and to the observations from the Bauru radar. The simulation results for ozone precursors are shown and discussed in Sect. 5. They are compared with the airborne and balloon-borne measurements performed in Eastern Brazil and published in the literature and with satellite observations of $\mathrm{CO}$ over Brazil. Particular attention is given to the impact of the production of $\mathrm{NO}_{\mathrm{x}}$ by lightning on the other ozone precursors in the convective area. The results for $\mathrm{HO}_{\mathrm{x}}$ and its precursors are analysed in Sect. 6. The conclusion of this study is summarised in Sect. 7.

\section{Description of the case study}

The beginning of February 2001 was characterized by a synoptic situation typical for summer in the State of São Paulo. In broad terms, it can be summed up by a high pressure system situated off the coast between the State of São Paulo and southern Brazil and ridging in over the continent, with a weak cold front extending along its northern flank across Rio de Janeiro into Minas Gerais. The other component was a large cyclone initially centred over north-western Argentina from where a tongue of moist air extended across Paraguay, Paraná and the State of São Paulo into Mato Grosso do Sul. Another important fact was the strong confluence of wind in the $700 \mathrm{hPa}$ level over the State of São Paulo, overlaid by an exceptionally strong divergence at levels from $500 \mathrm{hPa}$ upwards. The deep cyclone, which had developed over the southern part of the continent on 6 February 2001 had drastically intensified while moving south-eastwards, pushing the anticyclone eastwards off the central part of the continent and towards the ocean. A more detailed description of the synoptic situation is given in Held and Nachtigall (2002). On 8 February 2001 at 00:00 UT, an extremely strong confluence of moist maritime air was observed near the surface over the State of São Paulo at the $850 \mathrm{hPa}$ level, overlaid by a very strong inflow of tropical air at $500 \mathrm{hPa}$ (see Fig. 1), and topped by significant divergence at $300 \mathrm{hPa}$.

The development of the convective storm, that caused flooding in the urban area of Bauru during the late afternoon on 8 February 2001, was well observed by the S-band radar located in Bauru $\left(22.4^{\circ} \mathrm{S}, 49.0^{\circ} \mathrm{W}\right.$ ) (Held and Nachtigall, 2002). The radar has a range of $450 \mathrm{~km}$ for surveillance every $30 \mathrm{~min}$. When operated in volume-scan mode every 15 or $7.5 \mathrm{~min}$, it is limited to a $240 \mathrm{~km}$ range, recording reflectivities and radial velocities. Around 15:00 UT (noon local time) on 8 February 2001, several storms already began to develop within the $240 \mathrm{~km}$ Bauru radar range with some of them reaching reflectivities greater than $60 \mathrm{dBZ}$ by 17:00 UT (14 local time, LT). Thereafter, the storms grew in size and intensity with more and more cells developing and merging into large complexes, especially in the north-north east to east-south east sector between 60 to $200 \mathrm{~km}$ range from the Bauru radar. Figure 2 shows the radar reflectivity at $1.7^{\circ} \mathrm{el}-$ evation (near the surface) from the Bauru radar at 18:00 UT, 20:00 UT and 22:00 UT. From 23:00 UT the system started to decay rapidly while moving slowly towards north-west. 

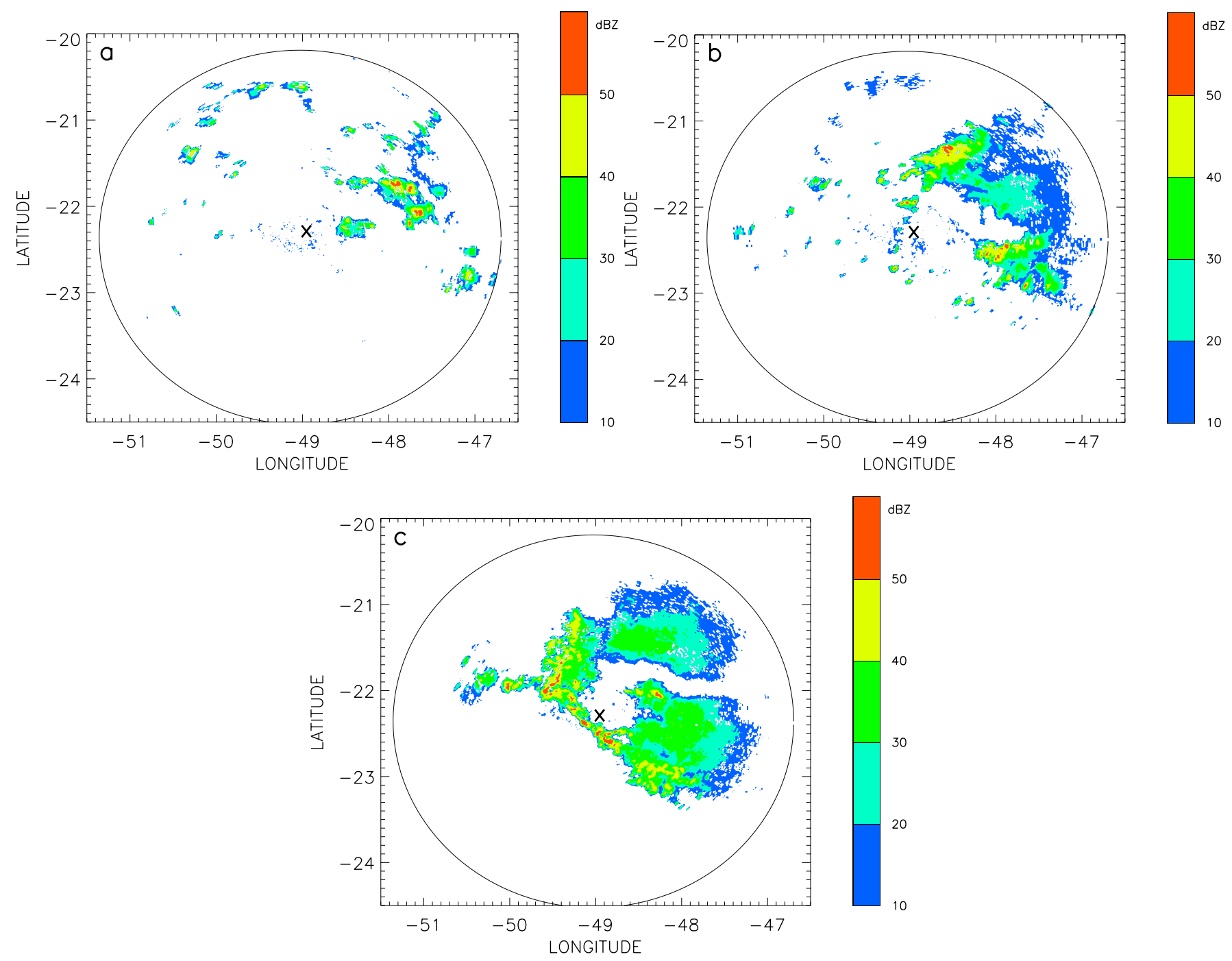

Fig. 2. Radar reflectivity in $\mathrm{dBZ}$ from the Bauru radar at $1.7^{\circ}$ elevation with a $240 \mathrm{~km}$ range (a) at 18:00 UT, (b) 20:00 UT and (c) 22:00 UT.

The cloud tops derived from the radar volume scans during the convective event showed that the most intense cells of the system generally reached $15-16 \mathrm{~km}$ altitude (not shown). A small proportion of them were penetrating the tropopause up to $18-19 \mathrm{~km}$ altitude.

\section{Numerical model}

The model used in the present study is called hereafter the "RAMS-Chemistry" model. It is composed of the Regional Atmospheric Modeling System (RAMS) coupled online with a chemistry model. RAMS (Pielke et al., 1992) is a primitive equation prognostic model that simulates threedimensional atmospheric circulations and weather systems. The RAMS version used in this study is the 4.3 version (Cotton et al., 2003). RAMS has a multiple grid nesting scheme solving the model equations simultaneously on interacting computational meshes of differing spatial resolution (Clark and Farley, 1984; Clark and Hall, 1991, Walko et al., 1995a).

The simulation discussed in the present paper includes two grid areas that are illustrated in Fig. 3. The coarse grid (Grid 1) covers a $3000 \mathrm{~km}$ by $2500 \mathrm{~km}$ domain from $60.8^{\circ} \mathrm{W}$ to $29.2^{\circ} \mathrm{W}$ in longitude and from $10.8^{\circ} \mathrm{S}$ to $32.7^{\circ} \mathrm{S}$ in latitude. Its horizontal grid spacing is $20 \mathrm{~km}$. The fine grid (Grid 2) domain is $628 \mathrm{~km}$ by $608 \mathrm{~km}$ with a $4 \mathrm{~km}$ grid spacing. Grid 2 includes the Bauru radar coverage area, in which the convective system developed on 8 February 2001, and the Metropolitan area of São Paulo. For both grids, the vertical coordinate is a terrain-following height coordinate with 61 levels from the surface to $30 \mathrm{~km}$ altitude with a $500 \mathrm{~m}$ spacing in the UTLS. The timesteps used are 30 and $10 \mathrm{~s}$ for Grid 1 and Grid 2, respectively.

The cloud microphysics is the explicit single moment bulk scheme from Walko et al. (1995b) which includes five 


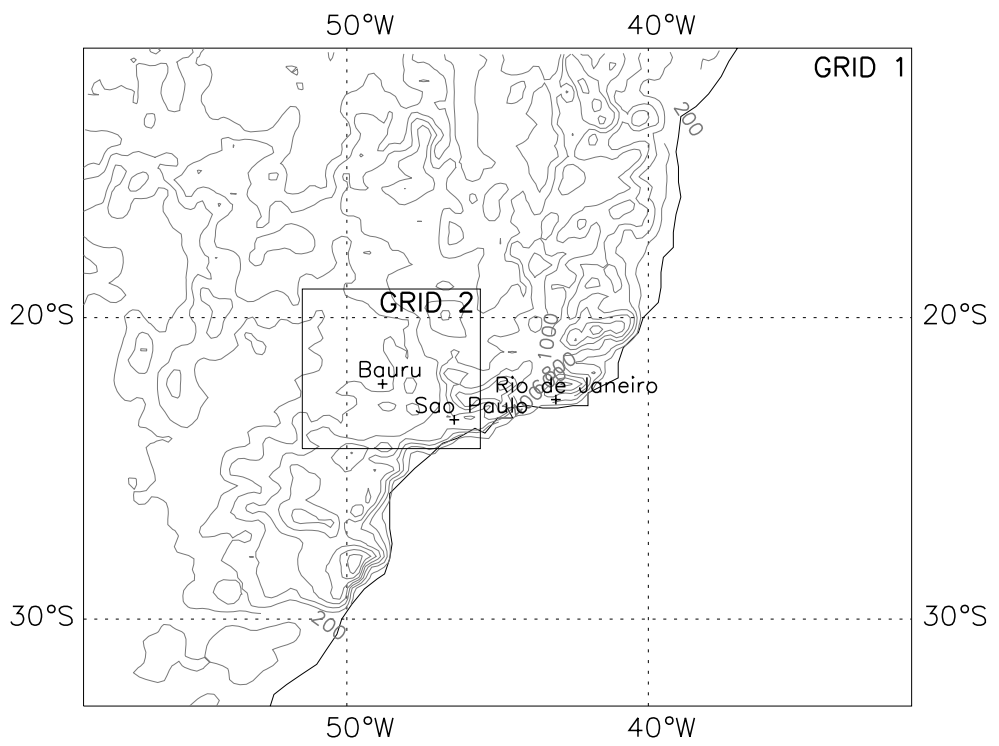

Fig. 3. Schematic showing the location of the two model grids.

categories of ice particles. For Grid 1, a convection parameterization is used to represent sub-gridscale convective processes. The parameterization chosen is from by Grell (1993) and Grell and Devenyi (2002) and implemented in the RAMS by Freitas et al. (2004).

The initialization data is obtained from the ERA-40 (ECMWF Re-Analysis-40) analysis of 7 February 2001 at 12:00 UT, improved by assimilating the soundings and nearsurface station data at 12:00 UT located within Grid 1. The simulation lasts $42 \mathrm{~h}$. The lateral boundary conditions are from nudging every $12 \mathrm{~h}$ with large scale fields derived similarly as the initial condition fields, i.e., ECMWF analysis fields blended with radiosounding and near-surface station data except those used for model validation in Sect. 4.1. For the upper boundary condition, we used a rigid lid with a highviscosity layer between 25 and $30 \mathrm{~km}$ altitude to damp gravity waves. The soil moisture and temperature initialization was modified to use the ERA40 soil analysis fields instead of horizontally homogeneous fields. This change leads to a noticeable improvement of the time and localisation of the convective system.

In this study, RAMS is coupled on-line with a condensed version of the MOCA 2.2 model (Aumont et al., 1996). This model, which was previously validated, has proved its ability to simulate the chemistry evolution of the lower and midtroposphere at mid latitudes (Taghavi et al., 2004; Audiffren et al., 2004) and in the tropics (Poulet et al., 2004). The model includes 29 species and 64 gaseous reactions given in Taghavi et al. (2004) and Poulet et al. (2004). It allows the representation of the main processes driving the concentrations of nitrogen oxides $\left(\mathrm{NO}_{x}\right)$ and ozone in the troposphere, including the dry deposition. In order to account for a better representation of the $\mathrm{NO}_{y}$ species partitioning in the UTLS between $\mathrm{NO}_{\mathrm{x}}$ species and their reservoirs, seven more reactions were added in the present model:

$$
\begin{aligned}
& \mathrm{HNO}_{3}+\mathrm{OH}+\mathrm{M} \rightarrow \mathrm{NO}_{3}+\text { product } \\
& \mathrm{HNO}_{3}+\mathrm{h} v \rightarrow \mathrm{NO}_{2}+\mathrm{OH} \\
& \mathrm{N}_{2} \mathrm{O}_{5}+\mathrm{h} v \rightarrow \mathrm{NO}_{3}+\mathrm{NO}_{2} \\
& \mathrm{HNO}_{4}+\mathrm{h} v \rightarrow \mathrm{NO}_{2}+\mathrm{HO}_{2} \\
& \mathrm{PAN}+\mathrm{h} v \rightarrow \mathrm{NO}_{2}+\mathrm{CH}_{3} \mathrm{COO}_{2} \\
& \mathrm{NO}_{2}+\mathrm{O}^{3 \mathrm{P}} \rightarrow \mathrm{NO}\left(+\mathrm{O}_{2}\right) \\
& \mathrm{HO}_{2}+\mathrm{O}^{3 \mathrm{P}} \rightarrow \mathrm{OH}\left(+\mathrm{O}_{2}\right)
\end{aligned}
$$

leading to a total number of gaseous reactions in the model of 72. Please note that $\mathrm{O}^{3 P}$ is not a prognostic variable of the model. $\mathrm{O}^{3 P}$ is deduced from $\mathrm{O}_{2}$ and $\mathrm{O}_{3}$, assuming the balance between production and loss terms of $\mathrm{O}^{3 P}$. Aqueous phase chemistry for 9 species is included in the model (Grégoire et al., 1994). This allows taking into account the scavenging of the most soluble species such as $\mathrm{HNO}_{3}$ and $\mathrm{H}_{2} \mathrm{O}_{2}$. The $\mathrm{pH}$ in the liquid cloud phase is set to 4.93 , as computed by two different cloud chemistry models in Barth et al. (2003). A sensitivity simulation showed that the results are not significantly changed if a less acid $\mathrm{pH}$ value is used.

The parameterization proposed by Pickering et al. (1998) for the production of $\mathrm{NO}_{\mathrm{x}}$ by lightning $\left(\mathrm{LNO}_{\mathrm{x}}\right)$ was included in the chemistry model. Basically, the computation of the $\mathrm{LNO}_{\mathrm{x}}$ production is performed at each horizontal grid point. In this parameterisation, $\mathrm{LNO}_{\mathrm{x}}$ can be computed for two different cloud layers. The first layer made of mixed water and ice cloud lies up to the $-15^{\circ} \mathrm{C}$ level. The second layer just 
above contains only ice phase cloud. For each horizontal grid point, the maximum vertical velocity in the corresponding air column is used to calculate the flash rate within the column. A proportion number of flash within each layer is then computed, depending on the thickness of the layer. Finally for each cloud layer, a specific parameterization is used to compute the $\mathrm{NO}_{\mathrm{x}}$ production at each level (Price et al., 1997), depending on the layer flash rates and the thickness of two consecutive model layers.

The chemical solver is the Quasi-Steady State Approximation (Hesstvedt et al., 1978). Photolysis rates are estimated from the TUV model (Madronich and Flocke, 1999) with a time resolution of $15 \mathrm{~min}$. The time step for the chemistry module is $6 \mathrm{~s}$ for the coarser grid and of $2 \mathrm{~s}$ for the fine grid. For this study, a new initialization module was developed. The chemical species are now initialized from the global model MOCAGE fields (Peuch et al., 1999; Cathala et al., 2003; Josse et al., 2004) obtained from a 15 day simulation started 15 days before the beginning of our simulation. This provides a realistic three-dimensional description of the chemical state of the atmosphere for the model chemistry module.

An emission module (Poulet et al., 2004) is also included in the RAMS-Chemistry model in order to represent the surface emission for isoprene, anthropogenic NMVOCs, $\mathrm{NO}_{\mathrm{x}}$ and $\mathrm{CO}$. Emissions for NMVOCs, $\mathrm{NO}_{\mathrm{x}}$ and $\mathrm{CO}$ compounds are from the EDGAR (Emission Database for Global Atmospheric Research) 3.2 database (http://arch.rivm.nl/env/int/ coredata/edgar). The case study being during the wet season, the contribution of biomass burning to the emission of $\mathrm{CO}$, NMVOCs and $\mathrm{NO}_{\mathrm{x}}$ was not taken into account in the emission module. For isoprene, monthly mean data on a $1^{\circ} \times 1^{\circ}$ grid from the GEIA (Global Emissions Inventory Activity) database (http://weather.engin.umich.edu/geia) were used. The diurnal variation of isoprene emissions is taken into account as in Poulet et al. (2004).

\section{Validation of the meteorological results}

The spatial distribution of the chemical compounds largely depends on the meteorological fields. The wind field drives the transport process while the chemistry reactions (gaseous and aqueous) depend on the pressure, temperature, water vapour and water condensed fields. Therefore, it is necessary to evaluate the meteorological results before analysing the chemistry fields. Since the area of interest is where the convection develops, i.e., near Bauru, only the model results from the fine grid (Grid 2) are selected for comparison with observations.

\subsection{Statistical evaluation using surface observations}

The statistical evaluation method proposed by Wilmott (1981) is used to validate the model results using near sur- face measurements. This method was used in several studies in the past (e.g. Cai and Steyn, 2000; Taghavi et al., 2004). In the present paper, the evaluation measurements are from the ECMWF database with complementary data from INMET (Instituto Nacional de Meteorologia, Brazil) for the State of São Paulo. The available times are 00:00 UT, 06:00 UT 12:00 UT and 18:00 UT. Unfortunately, only data from four stations are available at 06:00 UT leading to a poor statistical meaning for this time. Thus, no results for the 06:00 UT are presented. Tables 1, 2 and 3 give a summary of the model statistical performances to predict the 2-metre wind, the 2-metre temperature and the 2-metre relative humidity, respectively. For relative humidity, only the INMET data were available. The model means and standard deviations at different times show a generally good agreement with observations. The model tends to slightly overestimate the temperature on average at night (up to $1.7 \mathrm{~K}$ difference) and slightly underestimates it during daytime (up to $1.3 \mathrm{~K}$ difference). The model provides less variability for the relative humidity than in the observations. The index of agreement is a measure of the difference between the observations and the model fields (Cai and Steyn, 2000):

$d=1-\frac{\sum_{i=1}^{n}\left(P_{i}-O_{i}\right)^{2}}{\sum_{i=1}^{n}\left(\left|P_{i}-\bar{O}\right|+\left|O_{i}-\bar{O}\right|\right)^{2}}$

with $\mathrm{n}$ the number of observations, $O_{i}$ the observations, $P_{i}$ the model predicted results collocated in time and space with the observations $O_{i}$ and $\bar{O}$ the mean of the observations $O_{i}$. The index of agreement ranges from 0.0, connoting one of a variety of complete disagreements, to 1.0 , indicating perfect agreement between the observed and predicted observations. In Tables 1 and 2, the index of agreement ranges from 0.63 to 0.87 for the wind and from 0.68 to 0.80 for the temperature demonstrating that the model provides results in good agreement with near-surface measurements. For relative humidity, the index of agreement is slightly weaker than for temperature and wind. Considering that the humidity varies very rapidly when and where convection occurs, the model performs fairly well in simulating near-surface relative humidity for the studied convective cluster.

\subsection{Comparison with radar observations}

The surface rainfall accumulated between 8 February 2001 at 15:00 UT and 9 February 2001 at 00:00 UT derived from the Bauru radar observations, as well as that calculated by the model (Grid 2) are displayed in Fig. 4. This time interval corresponds to the life time of the convective event. The model agrees fairly well with the observations although the location of the cells is not exactly reproduced by the model. In particular, the convective band that flooded Bauru extends too far west in the model. There is little rain below $23.4^{\circ}$ latitude in both the radar observations and the model. When 
Table 1. Statistical results for the 2-metre wind speed. STD stands for the standard deviation. Mean and STD values are in $\mathrm{m} \mathrm{s}{ }^{-1}$.

\begin{tabular}{lcccccc}
\hline & $\begin{array}{c}\text { Number of } \\
\text { observations }\end{array}$ & $\begin{array}{c}\text { Mean from } \\
\text { observations }\end{array}$ & $\begin{array}{c}\text { Mean from } \\
\text { model }\end{array}$ & $\begin{array}{c}\text { STD from } \\
\text { observations }\end{array}$ & $\begin{array}{c}\text { STD from } \\
\text { model }\end{array}$ & $\begin{array}{c}\text { Index of } \\
\text { agreement }\end{array}$ \\
\hline 8 February 2001 at 00:00 UT & 22 & 0.88 & 0.88 & 1.22 & 1.13 & 0.82 \\
8 February 2001 at 12:00 UT & 22 & 1.93 & 1.16 & 1.75 & 0.96 & 0.63 \\
8 February 2001 at 18:00 UT & 23 & 1.73 & 2.01 & 1.77 & 1.75 & 0.87 \\
9 February 2001 at 00:00 UT & 21 & 1.51 & 1.85 & 1.58 & 2.05 & 0.81 \\
\hline
\end{tabular}

Table 2. Same as Table 1 but for the 2-metre temperature in K.

\begin{tabular}{lcccccc}
\hline & $\begin{array}{c}\text { Number of } \\
\text { observations }\end{array}$ & $\begin{array}{c}\text { Mean from } \\
\text { observations }\end{array}$ & $\begin{array}{c}\text { Mean } \\
\text { from model }\end{array}$ & $\begin{array}{c}\text { STD from } \\
\text { observations }\end{array}$ & $\begin{array}{c}\text { STD from } \\
\text { model }\end{array}$ & $\begin{array}{c}\text { Index of } \\
\text { agreement }\end{array}$ \\
\hline 8 February 2001 at 00:00 UT & 21 & 297.9 & 299.6 & 2.0 & 2.0 & 0.74 \\
8 February 2001 at 12:00 UT & 21 & 298.8 & 297.8 & 2.1 & 2.0 & 0.80 \\
8 February 2001 at 18:00 UT & 21 & 301.4 & 300.1 & 3.8 & 2.5 & 0.68 \\
9 February 2001 at 00:00 UT & 20 & 296.6 & 297.8 & 2.8 & 2.2 & 0.69 \\
\hline
\end{tabular}

evaluating the model rainrates versus the radar rainrates, one has to take into account the high complexity of the convective event studied. This is an extended cluster composed of many intense convective cells. For this type of non-organized system, it is not possible to simulate exactly the development of each individual cell.

The model provides maxima of accumulated rainfall rates greater than the observed ones in convective cells. This can be partly due to the conversion algorithm used to calculate the rainfall rate from the radar reflectivity. For operational purposes, a Marshall-Palmer distribution is assumed, which maybe not appropriate for Brazilian convection. Furthermore, the resolution of the radar fields is $1 \times 1 \mathrm{~km}$, providing more details than the $4 \times 4 \mathrm{~km}$ of Grid 2 . Nevertheless, the model provides rainfall rates in fairly good agreement with the radar observations during the time of the convective event. After 00:00 UT on 9 February 2001, the convective system tends to dissipate in the simulation results but less rapidly than in the radar observations. During the convective event, the individual cells simulated by RAMS often reach 15 to $16 \mathrm{~km}$ altitude (not shown). This is consistent with the cloud top measurements derived from the Bauru radar observations for the same period. The model predicts for several convective cells a maximum altitude reaching the $16.9 \mathrm{~km}$ model level which is about the cold point tropopause altitude ( $\sim 17 \mathrm{~km}$ altitude). It never simulates convective cells reaching an altitude above the tropopause, unlike the cloud top radar observations. Even though it will not be possible to analyse from the present simulation a case of "overshooting" (when the convective updraft crosses the tropopause), it is interesting to study the impact of the very high simulated cells on the uppermost troposphere and LS.

\section{Results on ozone precursors}

\subsection{Results for CO}

To check the validity of the model results for CO, comparisons with MOPITT (Measurements Of Pollution In The Troposphere) measurements (Version 3) were performed. MOPITT is an instrument on board the Terra satellite flying on a sun-synchronous orbit (http://www.atmosp.physics.utoronto. $\mathrm{ca} / \mathrm{MOPITT} / \mathrm{home} \cdot \mathrm{html}$ ). It provides nadir measurements of pollutants in the troposphere and in particular CO measurements in cloud-free conditions (Deeter et al., 2004). Since there was no sampling by MOPITT of the model domain during the simulation time period, a statistical approach is chosen for the comparison allowing us to check that, on average, the model $\mathrm{CO}$ values are consistent with the observations. The MOPITT CO data averaged for the month of February 2001 and gridded on a $1^{\circ}$ by $1^{\circ}$ map are used. To make a fair comparison, the model $\mathrm{CO}$ profiles should be smoothed by the MOPITT averaging kernels. This can only be done for coincident MOPITT data. Nevertheless, it is possible to approximate the MOPITT averaging kernels at $700 \mathrm{hPa}$ by averaging the model $\mathrm{CO}$ between $700 \mathrm{hPa}$ and $500 \mathrm{hPa}$ After Deeter et al. (2003) and Deeter et al. (2004), the averaging kernels for the retrieval pressure $700 \mathrm{hPa}$ are maximum at $700 \mathrm{hPa}$ and $500 \mathrm{hPa}$ over tropical oceanic areas. Since the model grid considered is half covered by tropical ocean and cloud-free areas are mainly over ocean for the model times considered, this approximation is reasonable.

Grid 2 is not considered here, since it only covers an area of about $6^{\circ}$ longitude by $6^{\circ}$ latitude and therefore it is not possible to make a significant statistical comparison with the 
Table 3. Same as Table 1 but for the 2-metre relative humidity in $\%$.

\begin{tabular}{lcccccc}
\hline & $\begin{array}{c}\text { Number of } \\
\text { observations }\end{array}$ & $\begin{array}{c}\text { Mean from } \\
\text { observations }\end{array}$ & $\begin{array}{c}\text { Mean from } \\
\text { model }\end{array}$ & $\begin{array}{c}\text { STD from } \\
\text { observations }\end{array}$ & $\begin{array}{c}\text { STD from } \\
\text { model }\end{array}$ & $\begin{array}{c}\text { Index of } \\
\text { agreement }\end{array}$ \\
\hline 8 February 2001 at 00:00 UT & 19 & 78.5 & 76.8 & 10.5 & 8.3 & 0.66 \\
8 February 2001 at 12:00 UT & 16 & 76.1 & 80.8 & 5.2 & 2.6 & 0.56 \\
8 February 2001 at 18:00 UT & 16 & 70.8 & 69.6 & 15.4 & 12.3 & 0.66 \\
9 February 2001 at 00:00 UT & 15 & 87.8 & 83.3 & 8.0 & 7.9 & 0.75 \\
\hline
\end{tabular}
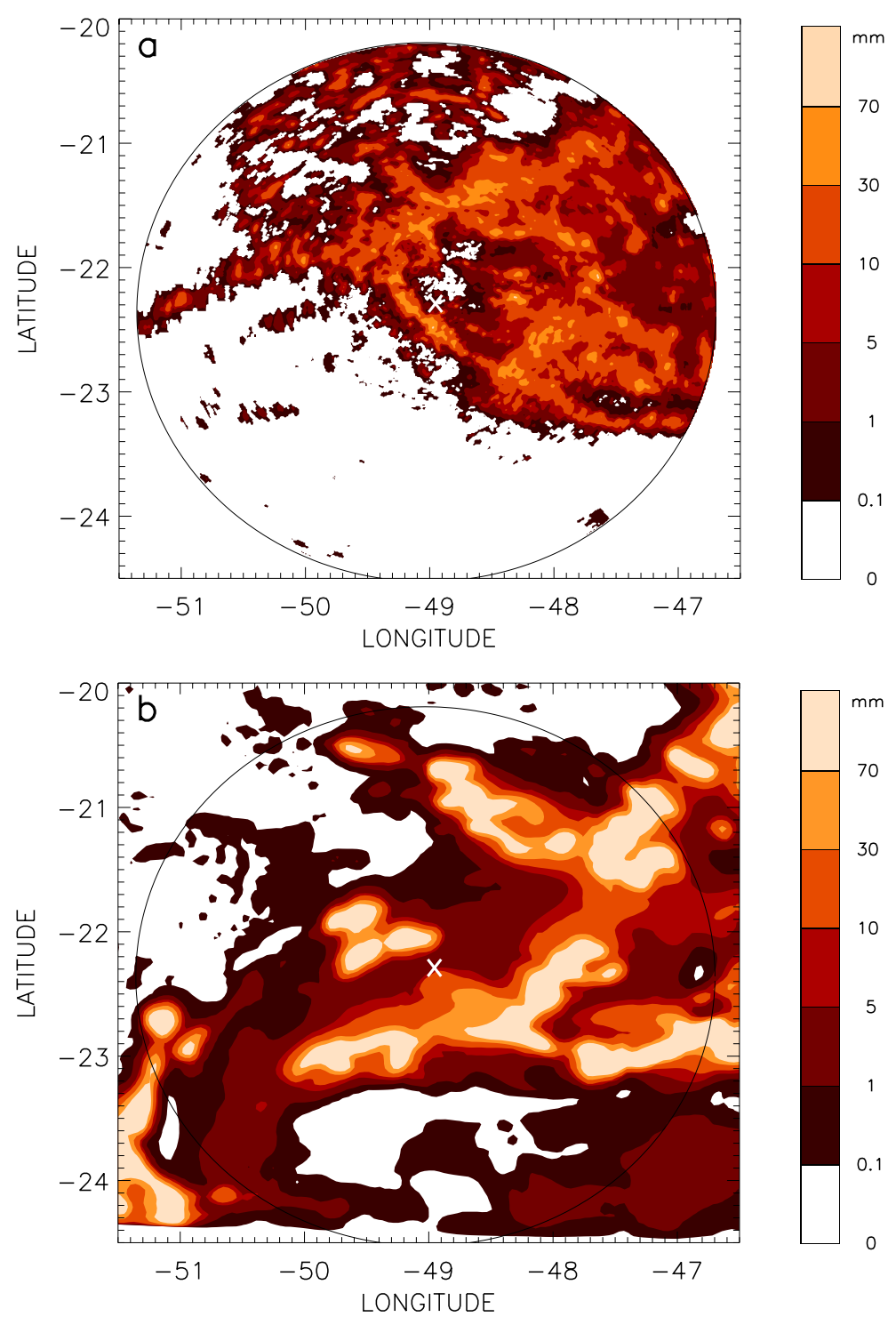

Fig. 4. Surface rainfall accumulated (in $\mathrm{mm}$ ) between 8 February 2001 at 15:00 UT and 9 February 2001 at 00:00 UT (a) derived from the Bauru radar observations and (b) calculated by the model.

MOPITT field. The model statistics are calculated using only cloud-free grid points to be consistent with MOPITT observations. Results of the comparison are given in Ta- ble 4. The model mean values obtained for different dates and times are close to the mean MOPITT value (within 5\%). This shows that the model provides realistic average values 

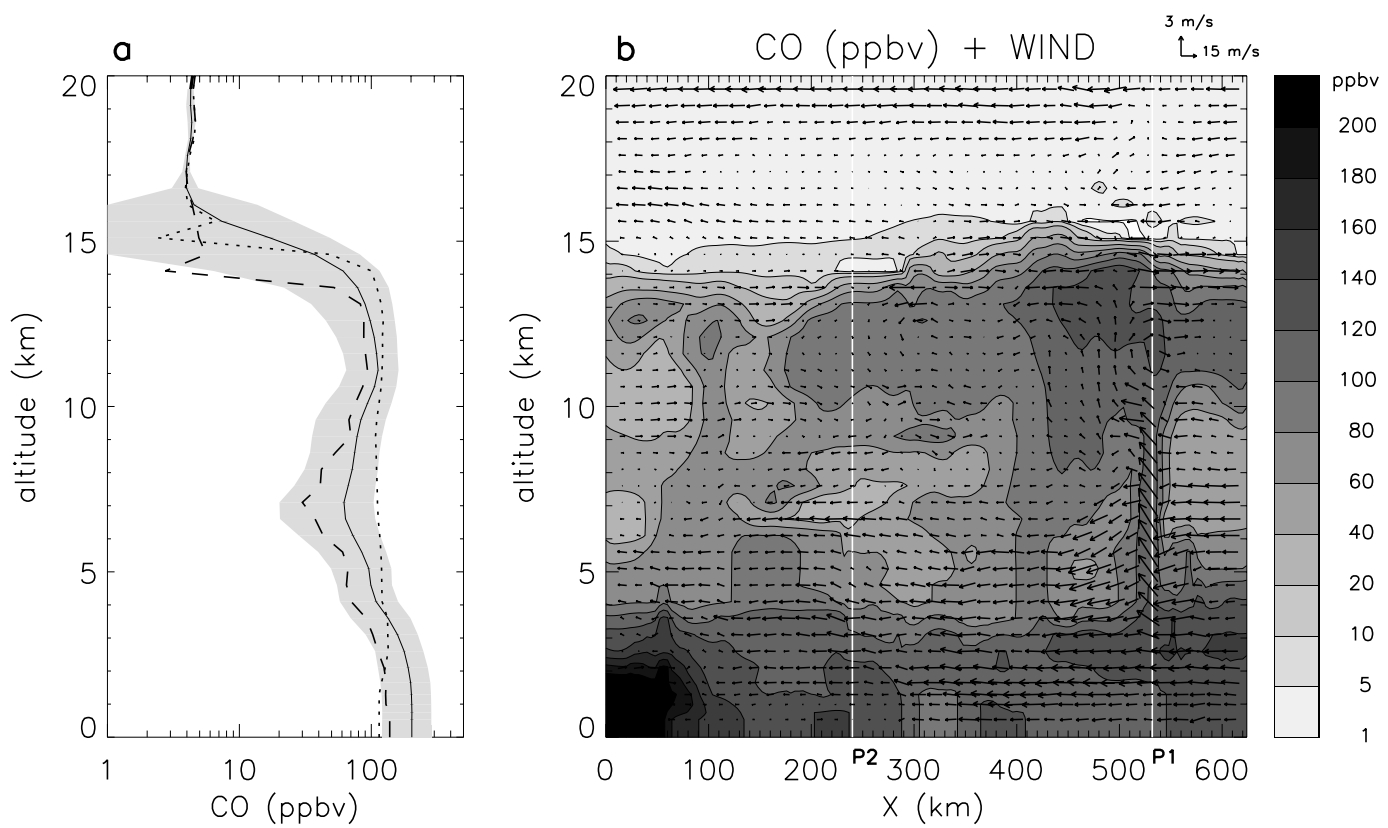

Fig. 5. Simulation results on 8 February 2001 at 22:00 UT. (a) CO averaged over the Grid 2 domain as a function of altitude (bold line) with logarithm scale in horizontal axis. Individual profiles P1 and P2 are also displayed with a dotted line and a dashed line, respectively. The grey area corresponds to the envelope of the mean $\mathrm{CO} \pm$ its standard deviation. (b) Vertical cross-section of $\mathrm{CO}$ (contours) and wind field (arrows) located at $-22.9^{\circ}$ latitude. The location of profiles $\mathrm{P} 1$ and $\mathrm{P} 2$ is also indicated by white lines.

Table 4. Statistical results for CO from MOPITT measurements at $700 \mathrm{hPa}$ for the month of February and from the model results for several dates and times. STD stands for the standard deviation.

\begin{tabular}{lcccc}
\hline & MOPITT & $\begin{array}{c}\text { Model 8 February } \\
\text { 2001 at 00:00 UT }\end{array}$ & $\begin{array}{c}\text { Model 8 February } \\
\text { 2001 at 12:00 UT }\end{array}$ & $\begin{array}{c}\text { Model 9 February } \\
\text { 2001 at 00:00 UT }\end{array}$ \\
\hline Mean (ppbv) & 91 & 90 & 92 & 96 \\
STD (ppbv) & 14 & 76 & 70 & 67 \\
\hline
\end{tabular}

of $\mathrm{CO}$ within the $700-500 \mathrm{hPa}$ layer. The model standard deviation is much larger $(\sim 70 \mathrm{ppbv})$ than the MOPITT standard deviation (14 ppbv). This can be explained by the fact that MOPITT measurements are averaged over a full month leading to a much smoother field than the model instantaneous fields and that MOPITT averaging kernels were approximated. Only small differences are found between the model statistics for different dates and times, indicating that the model results for the mean $\mathrm{CO}$ in the $700-500 \mathrm{hPa}$ layer do not significantly vary during the simulation period.

In order to analyse the impact of convection on the distribution of $\mathrm{CO}$, we will focus hereafter on the Grid 2 results since the convection process is explicitly simulated in Grid 2, meaning that no subgrid scale convection parameterization is used. Figure 5a shows the mean profile of $\mathrm{CO}$ on 8 February 2001 at 22:00 UT when the convective activity is strongest. It exhibits fairly large values of CO below $2 \mathrm{~km}$ altitude of about $20 \mathrm{ppbv}$. This is due to the large emissions of $\mathrm{CO}$ in the
Grid 2 domain which includes the São Paulo urban area. Up to about $7 \mathrm{~km}$ altitude, the $\mathrm{CO}$ mean profile decreases (minimum of $60 \mathrm{ppbv}$ ). Between 7 and $12 \mathrm{~km}$ altitude, the mean $\mathrm{CO}$ increases and reaches a maximum value of $120 \mathrm{ppbv}$. Above, $\mathrm{CO}$ decreases again up to the tropopause $(\sim 17 \mathrm{~km})$. In the LS, there are only small variations of the mean $\mathrm{CO}$ profile with altitude. Note also that the space variability of $\mathrm{CO}$ is much smaller in the stratosphere than in the troposphere as illustrated by the grey area in Fig. 5a. This indicates that the $\mathrm{CO}$ in the LS does not originate from the troposphere. The influence of the dynamics of the deep convective cells on the stratospheric $\mathrm{CO}$ is negligible since even the highest cells are not able to cross the isentropic barrier at the tropopause. CO can be considered as a passive tracer in the troposphere at the time scale of the simulation period ( $\sim 2$ days). Therefore, its vertical distribution is related to transport that is mainly due to convection in the present case study. To interpret the mean $\mathrm{CO}$ profile, we have also plotted the vertical cross-section 

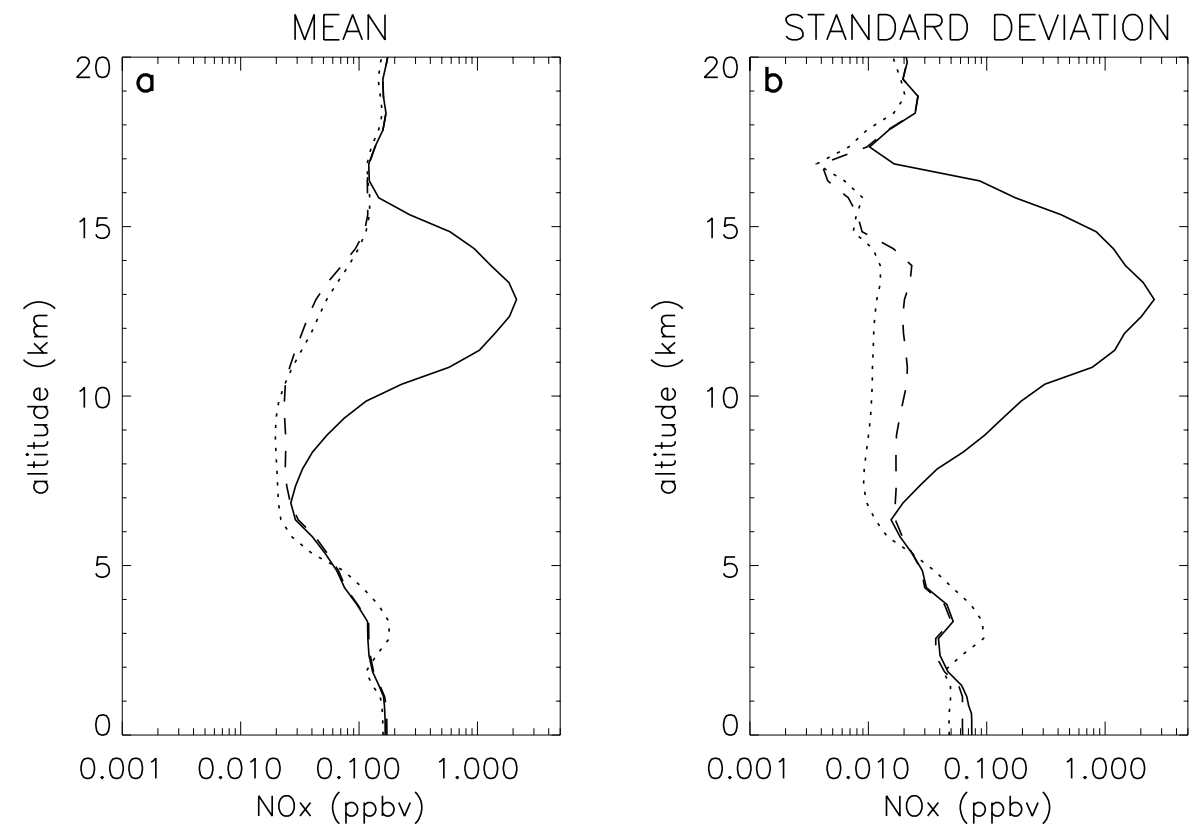

Fig. 6. (a) Mean of $\mathrm{NO}_{\mathrm{x}}$ mixing ratio over the Grid 2 domain as a function of altitude and (b) corresponding standard deviation. The solid, dotted and dashed lines correspond respectively to the reference run at 22:00 UT on 8 February 2001, the reference run at 22:00 UT on 7 February 2001 and the "No LNO " run at 22:00 UT on 8 February 2001. In horizontal axis, the scale is logarithm.
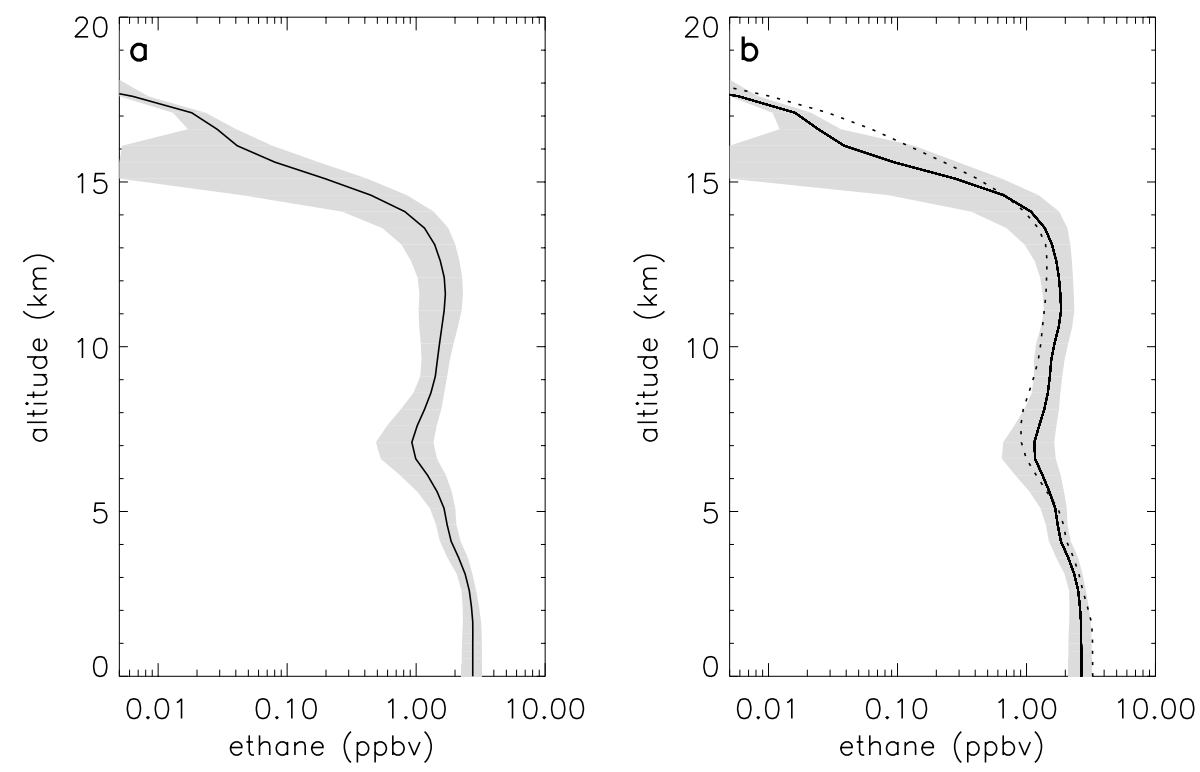

Fig. 7. Mean ethane mixing ratio over Grid 2 domain as a function of altitude for the reference run (a) on 8 February 2001 at 18:00 UT and (b) on 8 February 2001 at 22:00 UT (solid line) and on 7 February 2001 at 22:00 UT (dotted line). The grey area corresponds to the envelope of the mean ethane \pm its standard deviation. In horizontal axis, the scale is logarithm.

of wind together with the $\mathrm{CO}$ mixing ratio at $-22.9^{\circ}$ latitude (Fig. 5b). This cross-section intercepts both convective and non-convective areas. Within the convective cells, the $\mathrm{CO}$ emitted at the surface is rapidly transported to the top of the ascent. At $-46.5^{\circ}$ longitude, the P1 profile (dotted line) exhibits nearly constant values up to $14 \mathrm{~km}$ altitude. The updraft leads to a profile with only small variations of $\mathrm{CO}$ with altitude up to the top of convection, as illustrated in Fig. 5a. Above, $\mathrm{CO}$ decreases rapidly to reach stratospheric values ( $\sim 4 \mathrm{ppbv})$. The behaviour of the CO profile outside the con- 

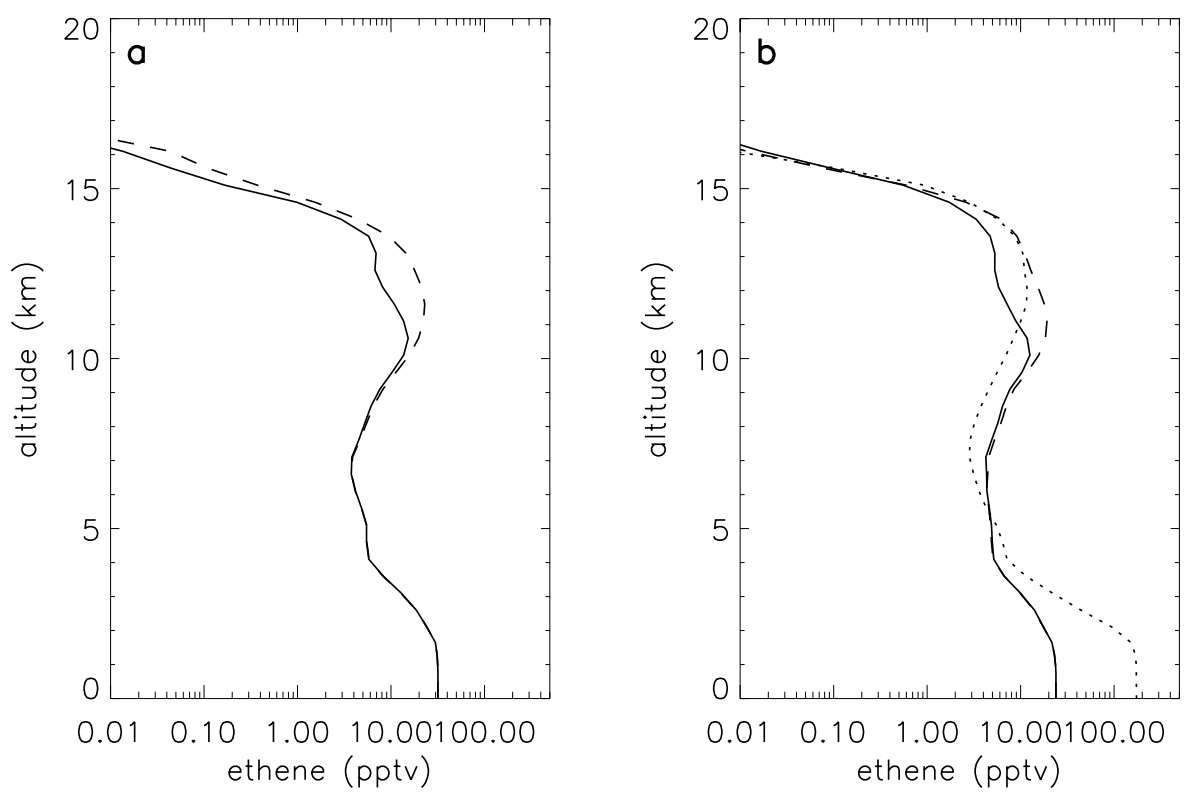

Fig. 8. Mean ethene mixing ratio over Grid 2 domain as a function of altitude for the reference run (solid line) and the "No $\mathrm{LNO}_{\mathrm{x}}$ " run (dashed line) (a) on 8 February 2001 at 18:00 UT and (b) on 8 February 2001 at 22:00 UT. In (b), the dotted line corresponds to the reference run on 7 February 2001 at 22:00 UT. In horizontal axis, the scale is logarithm.
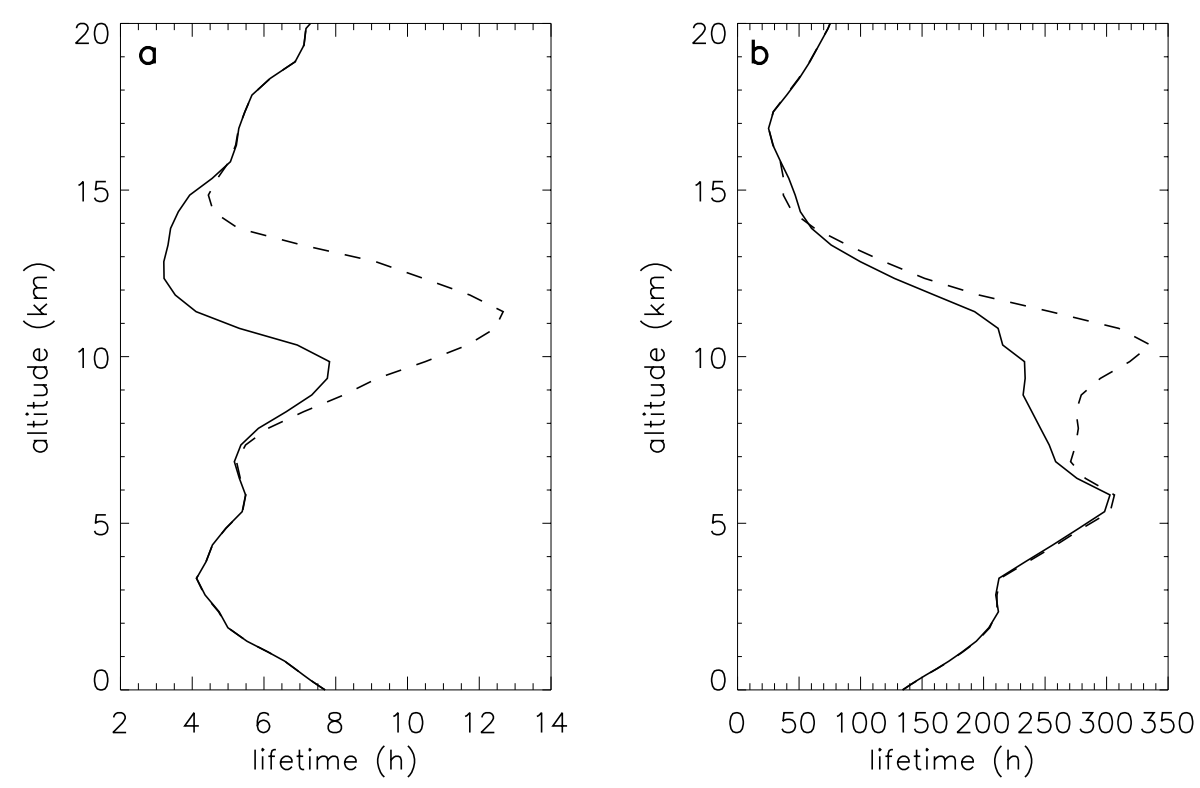

Fig. 9. Lifetime of ethene in $\mathrm{h}$ as a function of altitude for the reference run (solid line) and the "No $\mathrm{LNO}_{\mathrm{x}}$ " run (dashed line) (a) on 8 February 2001 at 18:00 UT and (b) on 8 February 2001 at 22:00 UT.

vection differs from that within the convective cells. This is shown in Fig. 5a, depicting the profile $\mathrm{P} 2$ at $-49.3^{\circ}$ longitude (dashed line). In this case, there is a decrease of $\mathrm{CO}$ up to $7 \mathrm{~km}$ as in the mean $\mathrm{CO}$ profile, because there is no updraft to transport $\mathrm{CO}$ surface emissions. Above $7 \mathrm{~km}$ and below the tropopause, the increase of the $\mathrm{CO}$ values is due to the horizontal transport of the large $\mathrm{CO}$ amounts from the top of the nearby convective cells. Once the large $\mathrm{CO}$ mixing ratios emitted at surface have been transported rapidly into the UT by the convective ascents, it is rapidly spread by convective outflow and horizontal winds. Most of $\mathrm{CO}$ amounts remain in the UT during the simulation time. Only a small part of it is slowly descending through weak downdrafts. These results are consistent with the recent study of Salzmann et 
al. (2004) based on a cloud-resolving model. They showed that the tracers emitted in the boundary layer and vertically transported by convection remain in the UT for several days, but only if large-scale forcing is considered in their model. In this case, they found that the large-scale tropospheric ascent partially compensates the net-downward transport of tracers due to the mesoscale subsidence induced by deep convection.

The results for CO shown in Fig. 5a were compared with those found by Jonquières and Marenco (1998) from TROPOZ II (TROPOspheric Ozone experiment) observations over Eastern Brazil. The TROPOZ II CO mixing ratios vary from $110 \mathrm{ppbv}$ near the surface to $60-70 \mathrm{ppbv}$ in the 2$7 \mathrm{~km}$ layer while between 7 and $10 \mathrm{~km}$ altitude (top of the observations), there was a significant increase of $\mathrm{CO}$ up to $120 \mathrm{ppbv}$ at $10 \mathrm{~km}$ altitude. Jonquières and Marenco (1998) interpreted this behaviour as a consequence of convective activity. The model results in the convective area (i.e. Grid 2) show a good consistency with the TROPOZ II measurements since the shape of the model mean CO is similar to the observations with large values near the surface, a decrease between 2 and $7 \mathrm{~km}$ and an increase between 7 and $10 \mathrm{~km}$ altitude. Moreover, at any level, the observed values fall within the model variability illustrated by the area between the mean \pm the standard deviation (grey area in Fig. 5a). The mean CO profile plotted in Fig. 5a illustrates the typical behaviour of tracers in the presence of deep convection. This typical profile can be divided in 4 layers: layer 1 up to $2 \mathrm{~km}$ where the surface emission dominates, layer 2 from 2 to $7 \mathrm{~km}$ where the concentration of tracers decreases, layer 3 (or "bulge" layer) from $7 \mathrm{~km}$ to the tropopause where there is an enhancement of tracer mixing ratios related to the effect of upward transport by convective ascents only partially compensated by a weaker downward transport, and layer 4 , above the tropopause, where stratospheric conditions prevail.

\subsection{Results for $\mathrm{NO}_{\mathrm{x}}$}

Figure 6a shows the mean $\mathrm{NO}_{\mathrm{x}}\left(\mathrm{NO}+\mathrm{NO}_{2}\right)$ profile in Grid 2 at 22:00 UT on 8 February 2001, time of the maximum of convective activity. To study the effect of convection on the $\mathrm{NO}_{\mathrm{x}}$ vertical distribution, this profile is compared to the mean $\mathrm{NO}_{\mathrm{x}}$ profile at 22:00 UT on 7 February 2001, i.e. before the convection developed (dotted line in Fig. 6a). The same time of the day is chosen for the two mean profiles since the production and loss of $\mathrm{NO}_{\mathrm{x}}$ highly depend on the solar flux. This allows the study of the impact of only the convection process on the $\mathrm{NO}_{\mathrm{x}}$ vertical distribution, independently of the solar conditions.

Below $\sim 7 \mathrm{~km}$ altitude, the two mean profiles are close and also have similar standard deviations. The differences found around $3 \mathrm{~km}$ altitude may be attributed to local dynamical effects. The mean profile at the time of the maximum of convection, i.e. 22:00 UT on 8 February 2001, exhibits a large increase of the mean and standard deviation values between $7 \mathrm{~km}$ and $17 \mathrm{~km}$ altitude compared to the values found $24 \mathrm{~h}$ before, when the convection system has not developed yet. At 22:00 UT on 8 February 2001, the mean $\mathrm{NO}_{\mathrm{x}}$ mixing ratio reaches $2 \mathrm{ppbv}$ at $\sim 13 \mathrm{~km}$ altitude, while at the same altitude it is only around $0.05 \mathrm{ppbv}$ one day before. To test whether this difference is related to the production of $\mathrm{NO}_{\mathrm{x}}$ through lightning originated by the convection, an additional simulation was run. This new model run is similar to the reference run described in Sect. 3, but does not include the parameterization of the $\mathrm{NO}_{\mathrm{x}}$ production by lightning during the whole simulation duration. This sensitivity run is called the "No $\mathrm{LNO}_{\mathrm{x}}$ " run hereafter. In the "No $\mathrm{LNO}_{\mathrm{x}}$ " run at 22:00 UT on 8 February 2001 (dashed line in Fig. 6), there is no significant increase of the $\mathrm{NO}_{\mathrm{x}}$ mixing ratio in the $7-17 \mathrm{~km}$ layer with respect to the reference run at 22:00 UT on 7 February 2001 while large differences are found with respect to the reference run at 22:00 UT on 8 February 2001. The $\mathrm{NO}_{\mathrm{x}}$ distribution is mainly determined by the production of $\mathrm{NO}_{\mathrm{x}}$ by lightning which provides larger amounts of $\mathrm{NO}_{\mathrm{x}}$ than the vertical transport of emission. Therefore, there is a very large impact of convection in the UT on the $\mathrm{NO}_{\mathrm{x}}$ mixing ratio, via the lightning process, leading to a possible effect on the ozone budget.

In the $17-20 \mathrm{~km}$ layer, the mean and standard deviation profiles from the reference run and the "No $\mathrm{LNO}_{\mathrm{x}}$ " run are very close. This seems to indicate that, on average, there is no vertical transport from the layer below $(7-17 \mathrm{~km})$ towards this layer, meaning through the cold point tropopause. This hypothesis was confirmed by the calculation of the $\mathrm{NO}_{\mathrm{x}}$ flux through the $17 \mathrm{~km}$ level (i.e. approximately the cold point tropopause level) providing weak downward fluxes on average. As for $\mathrm{CO}$, this indicates that there is no dynamical impact of the convective cluster on the stratospheric $\mathrm{NO}_{\mathrm{x}}$ even if the convective cells sometimes nearly reach $17 \mathrm{~km}$ altitude.

\subsection{Results for NMVOCs}

The model results for the NMVOCs are displayed in Figs. 7, 8 and 10 showing the mean profile of ethane, ethene and isoprene in Grid 2. The NMVOC production/loss may largely depend on the solar radiation. Therefore, the NMVOC results are displayed for 7 February 2001 and 8 February 2001 for two different times: 18:00 UT (i.e. during day time) and 22:00 UT (i.e. during sunset). At 18:00 UT the convective system is still growing in intensity while at 22:00 UT the convective activity is at its maximum. The mean profiles at 18:00 UT on 7 February 2001 are not shown since the model is in its spin-up phase at this date/time.

Ethane $\left(\mathrm{C}_{2} \mathrm{H}_{6}\right)$ is a non-methane hydrocarbon. As such, ethane affects the oxidizing capacity of the troposphere by having an effect on the ozone budget. The mean ethane profile for the reference run during the convective event (solid line in Figs. 7a and b) exhibits a shape similar to the CO mean profile (see Fig. 5a) with a bulge of ethane in the 7$17 \mathrm{~km}$ layer. The reference run profile on 7 February 2001 at 22:00 UT (dotted line in Fig. 7b) provides larger values 

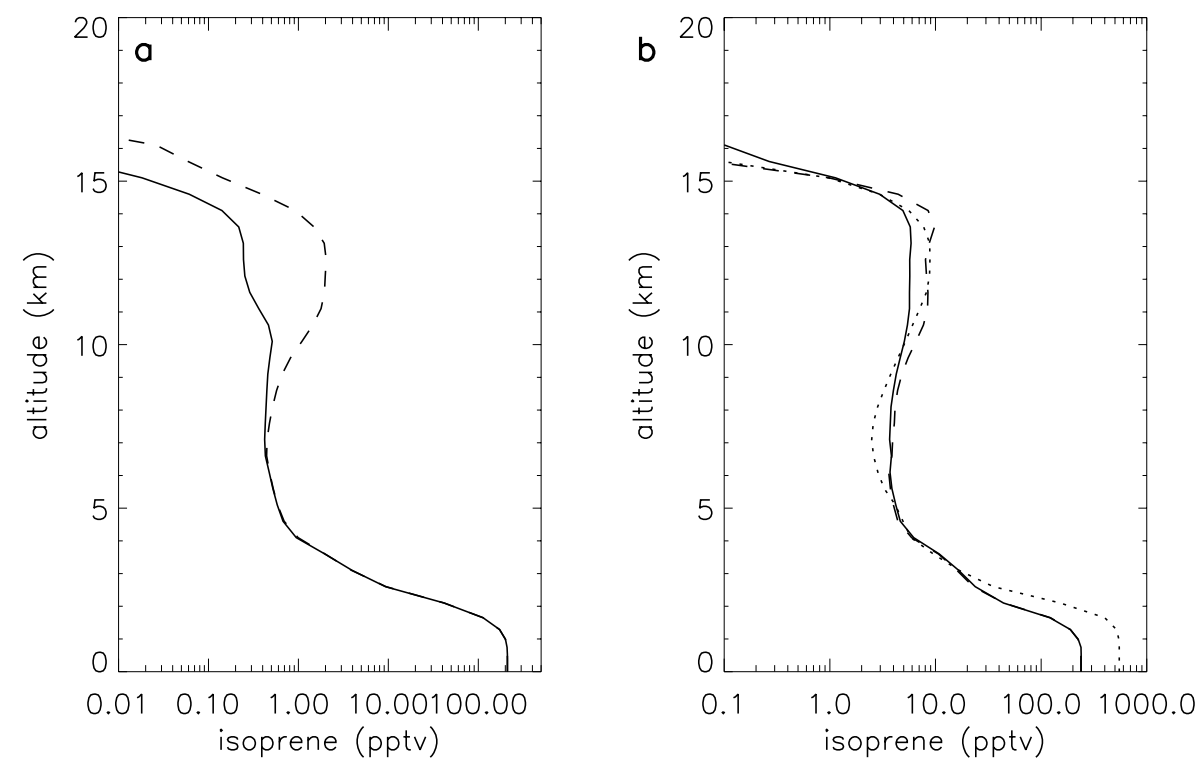

Fig. 10. Same as Fig. 8 but for isoprene.
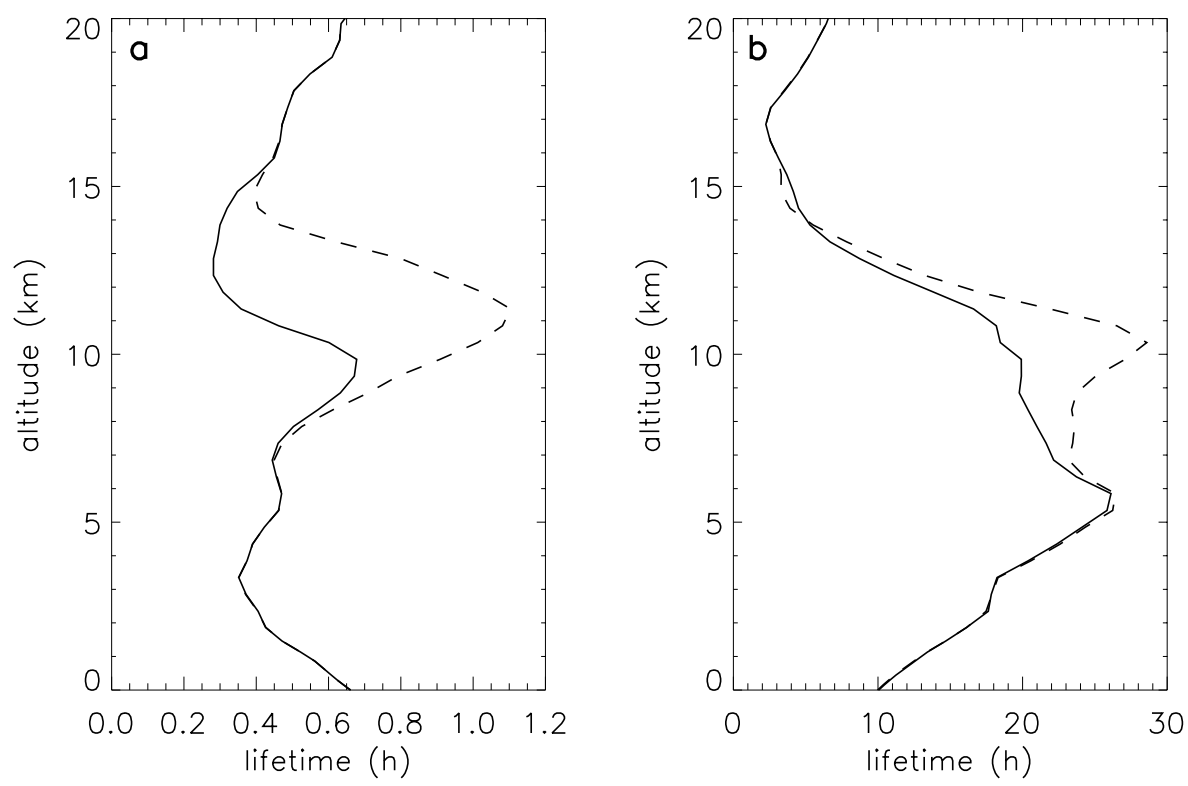

Fig. 11. Same as Fig. 9 but for isoprene.

of ethane in the low levels and weaker values in the "bulge layer" compared to 22:00 UT on 8 February 2001. This shows that between these two dates, the ethane emitted at surface was lifted by convection in the UT. The profiles for the "No $\mathrm{LNO}_{\mathrm{x}}$ " run at 18:00 UT and at 22:00 UT have not been plotted in Fig. 7, because there are only negligible differences compared to the reference run. This indicates that ethane does not depend directly or indirectly on the $\mathrm{NO}_{\mathrm{x}}$ amount in the UT. Ethane is a slow reactive compound. Its lifetime is always greater than several tens of days whatever the time of the day considered. Therefore, ethane can be considered as a passive tracer at the time scale of the simulation. As for $\mathrm{CO}$, the ethane vertical distribution in the troposphere depends mainly on transport, photochemistry being negligible in the simulation. Boissard et al. (1996) reached a similar conclusion from the analysis of the TROPOZ II measurements over eastern Brazil. The ethane 2-D distributions from Boissard at al. (1996) indicate $0.7 \mathrm{ppbv}$ to $1.5 \mathrm{ppbv}$ between ground level and $11 \mathrm{~km}$ altitude (top of the observations). These values are within the model variability (shown as the grey area 


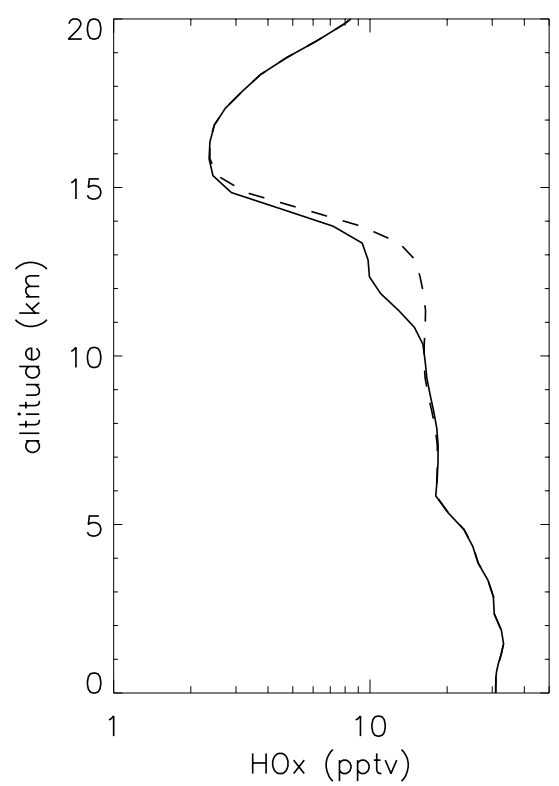

Fig. 12. Mean $\mathrm{HO}_{\mathrm{x}}$ mixing ratio over Grid 2 domain as a function of altitude for the reference run (solid line) and for the "No LNO run (dashed line) on 8 February 2001 at 18:00 UT.

in Fig. 7a) although the mean values from the model are generally greater (from $0.9 \mathrm{ppbv}$ to $2.5 \mathrm{ppbv}$ ) compared to the TROPOZ II observations. This can be explained by the fact that TROPOZ II flights were performed near the coast where emissions were probably lower than in the model Grid 2 box that includes the São Paulo urban area. In both the model and the TROPOZ II observations, the shape of the vertical distribution is similar: first a decrease followed by an increase. The location of the minimum is lower in the observations: about $4 \mathrm{~km}$ altitude against $7 \mathrm{~km}$ for the model. This may be related to the very high altitude of the 8 February 2001 convective ascents that transport surface emissions of ethane to high altitudes.

Figure 8 displays the results for ethene $\left(\mathrm{C}_{2} \mathrm{H}_{4}\right)$. The comparison between the reference run at 22:00 UT on 7 February 2001 and on 8 February 2001 shows that, similarly to ethane, convection transports the surface emission up to the UT. In the $7-17 \mathrm{~km}$ layer, the ethene lifted by convection is partially depleted in the reference run compared to the "No $\mathrm{LNO}_{\mathrm{x}}$ " run, both at 18:00 UT and at 22:00 UT. This means that the $\mathrm{NO}_{\mathrm{x}}$ produced by lightning have an impact on the ethene chemistry. Ethene loss is mainly due to reactions with $\mathrm{OH}$ that depend largely on the solar radiation. The lifetimes for ethene at 18:00 UT and 22:00 UT are displayed in Fig. 9. At 18:00 UT, the lifetime of ethene is around $5 \mathrm{~h}$, meaning that ethene is significantly depleted during the convective event duration. Moreover, at this time of the day, there are important differences of the lifetime between the reference run and the "No $\mathrm{LNO}_{\mathrm{x}}$ " run in the $7-17 \mathrm{~km}$ layer due to an increase of $\mathrm{OH}$ in the reference run and leading to the observed ethene loss in Fig. 8a. The origin of the $\mathrm{OH}$ increase is discussed in Sect. 6. At 22:00 UT, the ethene lifetime is always greater than $24 \mathrm{~h}$ because of the rapid decrease of $\mathrm{OH}$ at sunset. Therefore, the loss observed on Fig. $8 \mathrm{~b}$ between 7 and $15 \mathrm{~km}$ altitude is mainly due to the depletion of ethene by $\mathrm{OH}$ during the day time before 22:00 UT. In summary, the vertical distribution is of ethene depends on both dynamical effects increasing the ethene content in the UT and chemistry having the contrary effect.

Isoprene $\left(\mathrm{C}_{5} \mathrm{H}_{8}\right)$ is interesting, since it is the most reactive of the three compounds showed in this section. Figures 10 and 11 displays the mean isoprene profiles and the isoprene lifetimes, respectively. As for ethane and ethene, isoprene is transported to the UT by convective ascents leading to lower values of isoprene in the low levels and higher in the UT. At 18:00 UT, the lifetime of isoprene is around one hour meaning that this compound is depleted very rapidly though its reaction with $\mathrm{OH}$ at any level. This loss is even more important in the $7-16 \mathrm{~km}$ layer when the lightning $\mathrm{NO}_{\mathrm{x}}$ are taken into account since there is more $\mathrm{OH}$ is this case. At 22:00 UT, the differences between the isoprene lifetime for the reference and for the "No $\mathrm{LNO}_{\mathrm{x}}$ " runs are important between 7 and $11 \mathrm{~km}$ altitude. The lower values of isoprene in the reference run are related the loss that occurred during daytime.

Propene $\left(\mathrm{C}_{3} \mathrm{H}_{6}\right)$ is also an important NMVOC which is taken into account in the model. The results for propene (not shown) are similar those obtained for ethene and isoprene because its lifetime is between ethene and isoprene.

In the LS (above $17 \mathrm{~km}$ ), there are no significant changes of all the NMVOC contents even if the cloud top of several of the simulated convective cells nearly reach $17 \mathrm{~km}$ altitude. As for $\mathrm{CO}$ and $\mathrm{NO}_{\mathrm{x}}$, there is no penetration of any of the simulated convective cells through the isentropic barrier that could lead to troposphere-to-stratosphere transport.

\section{Results for $\mathrm{HO}_{x}$ and its precursors}

The distribution of $\mathrm{HO}_{\mathrm{x}}\left(\mathrm{OH}+\mathrm{HO}_{2}\right)$ in the atmosphere is of major importance in the ozone budget since the ozone precursors are oxidized through reactions with $\mathrm{HO}_{\mathrm{x}}$ to form ozone. Figure 12 represents the mean profiles for $\mathrm{HO}_{\mathrm{x}}$ at 18:00 UT on 8 February 2001 for the reference and the "No $\mathrm{LNO}_{\mathrm{x}}$ " runs. The 22:00 UT profile is not shown since this is the sun set time corresponding to a rapid decrease of $\mathrm{HO}_{\mathrm{x}}$ mixing ratios. The $\mathrm{HO}_{\mathrm{x}}$ mixing ratio for the "No $\mathrm{LNO}_{\mathrm{x}}$ " run is nearly constant between 10 and $13.5 \mathrm{~km}$ altitude. This is related to the vertical transport by convection of the $\mathrm{HO}_{\mathrm{x}}$ precursors as illustrated in Fig. 13 showing a bulge mainly for organic hydroperoxides (noted $\mathrm{ROOH}$ ) and formaldehyde (HCHO) in the UT. This result is consistent with the model results obtained by DeCaria et al. (2005) within the anvil of a midlatitude convective system. Another important $\mathrm{HO}_{\mathrm{x}}$ precursor (not shown here) is the water vapour. Its mean values are 

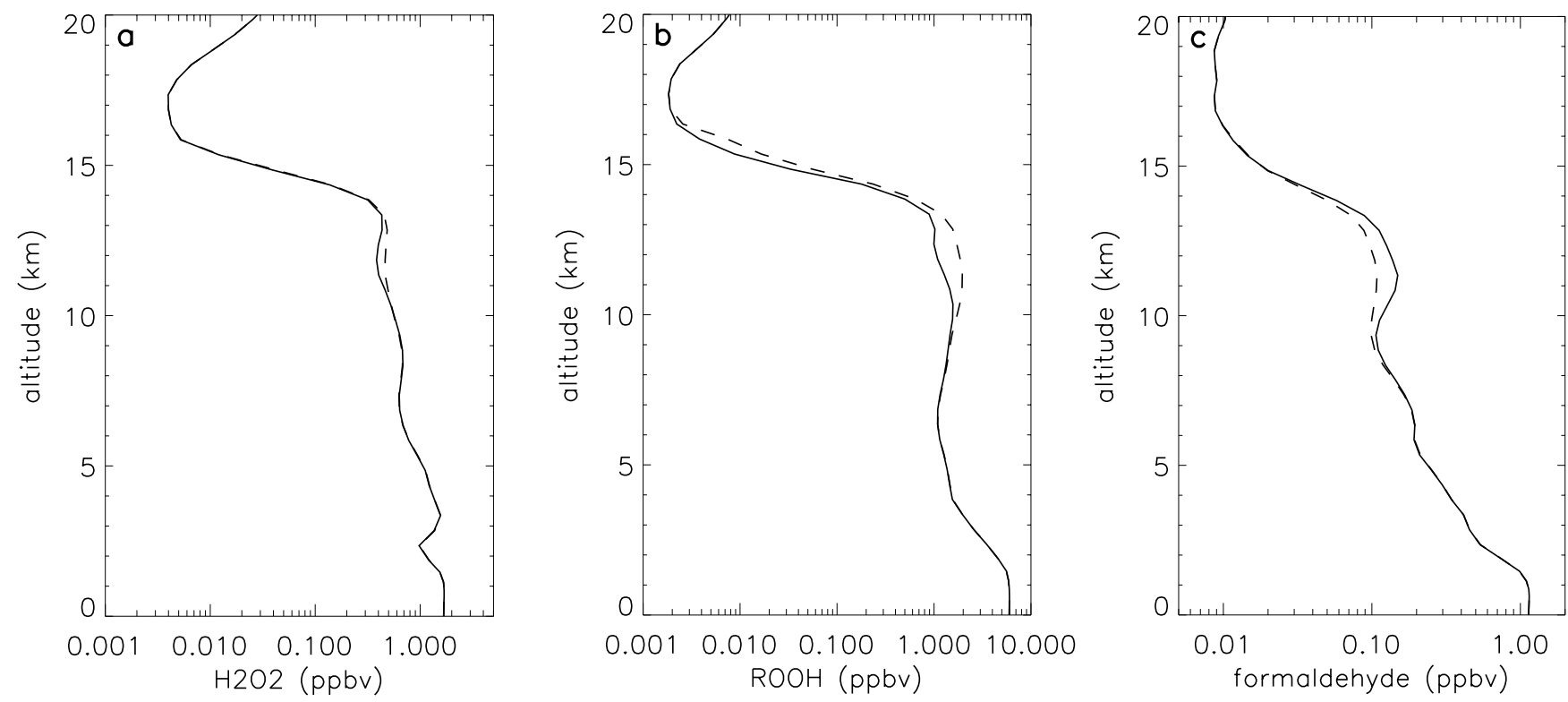

Fig. 13. Same as Fig. 12 but for (a) $\mathrm{H}_{2} \mathrm{O}_{2}$, (b) organic hydroperoxides (ROOH) and (c) formaldehyde.

increased by $12 \%$ at maximum in the UT during the convective period favouring the $\mathrm{HO}_{\mathrm{x}}$ production.

As illustrated in Figs. 12 and 13, there is a significant impact of the lightning $\mathrm{NO}_{\mathrm{x}}$ on $\mathrm{HO}_{x}$ and its precursors. The $\mathrm{HO}_{\mathrm{x}}$ mean profiles for the two runs are similar except in the $10-16 \mathrm{~km}$ altitude range where there is an important decrease of the reference run compared to the "No $\mathrm{LNO}_{\mathrm{x}}$ " run. This result is consistent with the mean $\mathrm{HO}_{\mathrm{x}}$ profile calculated by DeCaria et al. (2005). In their case, this decrease was associated to a decrease of both $\mathrm{HO}_{2}$ and $\mathrm{OH}$ while in the present study the model simulates on average a decrease of $\mathrm{HO}_{2}$ but an increase of $\mathrm{OH}$. The mechanism responsible for the $\mathrm{HO}_{2}$ decrease is similar in both studies: $\mathrm{HO}_{2}$ reactions with $\mathrm{NO}$ and $\mathrm{NO}_{2}$. For $\mathrm{OH}$, its production/loss depends on the relative quantity of $\mathrm{NO}_{\mathrm{x}}$ and VOCs (Volatile Organic Compound). In both simulations, VOC mixing ratios are high in the UT because of the convective uplift of the surface emissions and consecutive outflow. For the reference run, $\mathrm{NO}_{\mathrm{x}}$ mixing ratio is very high in the UT mainly where lightning is triggered. This leads to two types of mechanisms (Chapter 16 in Finlayson-Pitts and Pitts, 2000):

1. in very localized places where lightning $\mathrm{NO}_{\mathrm{x}}$ are produced, the ratio of VOC versus $\mathrm{NO}_{\mathrm{x}}$ is small enough to lead to $\mathrm{OH}$ depletion forming $\mathrm{HNO}_{3}$.

2. in other places in the vicinity of convective updrafts, a detailed analysis shows that the ratio of VOC versus $\mathrm{NO}_{\mathrm{x}}$ is large enough to lead to $\mathrm{OH}$ production.

On average, this is mechanism 2 that dominates in our simulation leading to a mean increase of $\mathrm{OH}$ while in DeCaria et al. (2005) this is mechanism 1 . This difference can be explained by different VOC emissions since the geographical regions considered are very different in the two studies. As in the present study, Wang and Prinn (2000) found an increase of $\mathrm{OH}$ during the daytime when $\mathrm{NO}_{\mathrm{x}}$ are produced by lightning from 2-D simulations of a cloud resolving model including chemistry. Using a global modelling approach, Labrador et al. (2004) and Jourdain (2003) obtained similar results on average.

As shown in Figs. 13a and b, lightning $\mathrm{NO}_{\mathrm{x}}$ tends to deplete organic hydroperoxydes and $\mathrm{H}_{2} \mathrm{O}_{2}$. This result is in agreement with DeCaria et al. (2005). The mean formaldehyde mixing ratio is enhanced in the $9-15 \mathrm{~km}$ layer by the increase of $\mathrm{NO}_{\mathrm{x}}$ by lightning. This is related to the fact that formaldehyde is formed and depleted at the same time by a complex chain of reactions. In fine, the loss term is of lesser importance, particularly at night time.

In the LS, there is no impact of convection on $\mathrm{HO}_{\mathrm{x}}$ and its precursors since the simulated convection cells do not cross the isentropic barrier at the tropopause. This result is similar to that found for the ozone precursors.

\section{Summary and conclusion}

In the literature, several papers have studied the impact of convection on the UTLS air composition from the cloud scale to the global scale in different regions (tropics and midlatitude). The goal of the present series of papers is to also analyse the influence of convection but for a type of convective system never studied before: an extreme non-organized tropical continental convective system. The model used in this study is the RAMS limited area model coupled on-line with a chemistry model. The case selected for this study is 
a severe and very deep convective event that caused flooding in the town of Bauru during the late afternoon of 8 February 2001.

The ERA-40 global analysis is used to initialise the model meteorological fields. For chemical species, MOCAGE global outputs are used. The model is run for two nested grids. The fine grid is focussed on the convective event area with a resolution of $4 \mathrm{~km}$ that allows the simulation of convection without using a sub-grid scale convection parameterization. Meteorological model fields were compared with the near-surface measurements of temperature, wind and relative humidity, as well as with the Bauru radar observations. The simulation provides results in fairly good agreement with these measurements.

Concerning the chemistry results, only the ozone precursors, $\mathrm{HO}_{\mathrm{x}}$ and its precursors are studied in the present paper. The study of the ozone distribution and budget done in the light of the present analysis is presented in the Part II of this series of papers. Two chemistry simulations were performed. The reference run includes the parameterization of production of $\mathrm{NO}_{\mathrm{x}}$ by lightning occurring in convective cells. The "No $\mathrm{LNO}_{\mathrm{x}}$ " run does not make use of this parameterisation. The simulated CO field for the reference run show a good agreement with MOPITT CO measurements for the month of February 2001 at $700 \mathrm{hPa}$. The model also shows a good agreement with TROPOZ II measurements of CO. CO is a passive tracer at the time scale of the simulation duration. In the convective area, its spatial distribution is closely linked to the dynamics of the convective system with a rapid uplifting of surface emissions by the updrafts and then with horizontal transport by the outflow at the top of convective cells. The effect of subsidence linked to convection is not strong enough to compensate the upward transport. This leads to larger amounts of CO in the $10-14 \mathrm{~km}$ layer. These dynamical effects of convection on $\mathrm{CO}$ are consistent with previous studies (Wang and Prinn, 2000; Tulet et al., 2002; Salzmann et al., 2004). Large quantities of $\mathrm{NO}_{\mathrm{x}}$, of up to $2 \mathrm{ppbv}$, are found in the mid and upper troposphere. These $\mathrm{NO}_{\mathrm{x}}$ are produced by lightning associated with the intense convective activity. The surface emissions of NMVOCs (ozone precursors) and $\mathrm{HO}_{\mathrm{x}}$ precursors are also transported by convection to the UT. One of the original results of this study is that the production of lightning $\mathrm{NO}_{\mathrm{x}}$ in the UT leads to a significant loss of the most reactive NMVOCs (isoprene, propene and ethene) via reactions with $\mathrm{OH}$ that is increased on average. This loss and the modification of the $\mathrm{HO}_{\mathrm{x}}$ budget influence the ozone production in the UT as discussed in part II of this series of papers. Lightning $\mathrm{NO}_{\mathrm{x}}$ tend to deplete $\mathrm{HO}_{2}$ and $\mathrm{HO}_{\mathrm{x}}$ precursors except formaldehyde that is enhanced. At the time of the maximum of convection (22:00 UT, i.e. $19 \mathrm{~h}$ local time), the chemical processes become less important since $\mathrm{HO}_{\mathrm{x}}$ mixing ratio in the troposphere is weaker during sunset. Another important result is that there is no modification of the mean ozone precursor contents in the LS for this extreme convective event. Even at the location of the highest simulated convective cells of the cluster, there is no upward transport through the tropopause isentropic barrier.

The aim of this series of papers is to analyse the impact of convection on the UTLS air composition. For this purpose, the study is done at the scale of the convective event, leading to the use of a fine resolution in the simulation. Therefore, only the local impact is studied at the time scale of the convective event $(\sim 12 \mathrm{~h})$. The evolution of ozone and ozone precursors in the tropical UTLS on longer time scales will be the subject of a future study.

To assess the quality of the simulation results, we have used the available chemical observations and data from the literature. Unfortunately, they are not sufficient to validate the model outputs. Therefore, the conclusions of the present paper need to be confirmed by field campaigns. This will be possible using the data from the coordinated HIBISCUS/TroCCiNO ${ }_{x} /$ TroCCiBras field campaign that took place in Brazil in February and March 2004. The results of the HIBISCUS/TroCCiNO $/$ /TroCCiBras campaign will help evaluating the parameterization of production of $\mathrm{NO}_{\mathrm{x}}$ by ligthning. As already pointed out by Labrador et al. (2004), this issue is important since it influences largely the $\mathrm{NO}_{\mathrm{x}}$ budget, and consequently the budget of NMVOCs, in the upper troposphere when tropical convection is active.

Acknowledgements. This modelling study is supported by funds from the $5^{\text {th }}$ PCRD (HIBISCUS project) and the French Centre National de le Recherche Scientifique (Programme National de Chimie Atmosphérique). One of the authors, E. D. Rivière was financially supported in this work by the HIBISCUS European project. This work makes use of the RAMS model, which was developed under the support of the National Science Foundation (NSF) and the Army Research Office (ARO). Computer resources were provided by CINES (Centre Informatique National de l'Enseignement Supérieur), project pce2227. The authors thank V.-H Peuch from Météo France for providing the MOCAGE fields that were used to initialise the chemistry model. We also acknowledge the MOPITT team at the National Center for Atmospheric Research (Boulder, CO USA) and J.-L. Attié for giving the CO gridded data from MOPITT measurements. We thank G. Foret from LaMP for helping with the use of the chemistry model, as well as INMET (Insituto Nacional de Meteorologia, Brazil) for providing surface observations. One of the authors, S. Freitas was financially supported by Fundação de Amparo à Pesquisa do Estado de São Paulo (\# 01/050125-4). Finally, we thank the referees for their helpful suggestions that improved the quality of the paper.

Edited by: M. G. Lawrence

\section{References}

Audiffren, N., Buisson, E., Cautenet, S., and Chaumerliac, N.: Photolytic impact of a stratocumulus cloud layer upon the chemistry of an offshore advected plume of pollutants during the NARE 1993 intensive experiment: a numerical study, Atmos. Res.,Vol $70, \mathrm{~N}^{\circ} 2,89-108,2004$. 
Aumont, B., Jaecker-Voirol,A., Martin, B., and Toupance, G.: Tests of some reduction hypotheses made in photochemical mechanisms, Atmos. Env., 30, 2061-2077, 1996.

Barth, M. C., Stuart, A. L., and Skamarock, W. C.: Numerical simulations of the 10 July 1996, Sratospheric-tropospheric experiment: radiation, aerosols and ozone (STERAO)- Deep convection experiment storm, redistribution of soluble tracers, J. Geophys. Res., 106(D12), 12 381-12 400, 2001.

Barth, M. C., Sillman, S., Hudman, R., Jacobson, M. Z., Kim, C.-H., Monod, A., and Liang, J.: Summary of the cloud chemistry modelling intercomparison, Photochemical box model simulation, J. Geophys. Res., 108(D7), 4214, doi:10.1029/2002JD002673, 2003.

Boissard, C., Bonsang, B., Kanakidou, M., and Lambert, G.: TROPOZ II: Global distributions and budgets of methane and light hydrocarbons, J. Atmos. Chem., 25, 115-148, 1996.

Cai, X.-M. and Steyn, D. G.: Modelling study of sea breezes in a complex coastal environment, Atmos. Env., 34, 2873-2885, 2000.

Cathala, M.-L., Pailleux, J., and Peuch, V.-H.: Improving global simulations of UTLS ozone with assimilation of MOZAIC data, Tellus, 55B, 1-10, 2003.

Clark, T. L. and Farley, R. D.: Severe downslope windstorm calculations in two and three spatial dimensions using the anelastic interactive grid nesting, A possible mecanism for gustiness, J. Atmos. Sci., 41, 329-350, 1984.

Clark, T. L. and Hall, W. D.: Multi-domain simulations of the time dependent Navier-Stokes equations: Benchmark error analyis of some nesting procedures, J. Comput. Phys., 92, 456-481, 1991.

Cotton, W. R., Pielke Sr., R. A., Walko, R. L., Liston, G. E., Tremback, C. J., Jiang, H., McAnelly, R. L., Harrington, J.-Y., Nicholls, M. E., Carrio, G. G., and McFadden, J. P.: RAMS 2001: Current status and future directions, Meteorol. Atmos. Phys., 82, 5-29, DOI 10.1007/s00703-001-0584-9, 2003.

DeCaria, A. J., Pickering, K. E., Stenchikov, G. L. and Ott, L. E.: Lightning-generated $\mathrm{NO}_{\mathrm{x}}$ and its impact on tropospheric ozone production: A three-dimensional modelling study of a Stratosphere-troposphere experiment, radiation, aerosols and ozone (STERAO-A) thurderstorm, J. Geophys. Res.,110, D14303, doi:10.1029/2004JD005556, 2005.

Deeter, M. N., Emmons, L. K., Francis, G. L., Edwards, D. P., Gille, J. C., Warner, J. X., Khattatov, B., Ziskin, D., Lamarque, J.-F., Ho, S.-P., Attié, J.-L., Packman, D., Chen, J., Mao, D., and Drummond, J. R.: Operational carbon $\mathrm{moNO}_{\mathrm{x}}$ ide retrieval algorithm and selected results for the MOPITT instrument, J. Geophys. Res., 108(D14), 4399, doi:10.1029/2002JD003186, 2003.

Deeter, M. N., Emmons, L. K., Edwards, D. P., and Gille, J. C.: Vertical resolution and information content of $\mathrm{CO}$ profiles retrieved by MOPITT, Geophys. Res. Letters, 31, L15112, doi:10.1029/2004GL020235, 2004.

Dickerson, R. R., Huffman, G. J., Luke, W. T., Nunnermacker, L. J., Pickering, K. E., Leslie, A. C. D., Lindsey, C. G., Slinn, W. G. N., Kelly, T. J., Daum, P. H., Delany, A. C., Greenberg, J. P., Zimmerman, P. R., Boatman, J. F., Ray, J. D., and Stedman, D. H.: Thunderstorms: an important mechanism in the transport of air pollutants, Science, 235, 460-465, 1987.

Finlayson-Pitts, B. J., and Pitts, Jr J. N. : Chemistry of the upper and lower atmosphere: theory, experiments and applications, Academic Press, San Diego, 2000.
Fishman, J., Hoell Jr, J. M., Bendura, R. D., McNeal Jr, R. J., and Kirchoff, V. W. J. H.: The NASA GTE TRACE-A experiment (September-October, 1992): Overview, J. Geophys. Res., 104, 23 865-23 880, 1996.

Freitas, S., Longo, K., Silva Dias, M., Silva Dias, P., Chatfield, R., Prins, E., Artaxo, P., Grell, G., and Recuero, F.: Monitoring the transport of biomass burning emissions in South America, Environmental Fluid Mechanics, Kluwer Academic Publishers, 5, 135-167, 2005.

Grégoire, P. J., Chaumerliac, N., and Nickerson, E. C.: Impact of cloud dynamics on tropospheric chemistry, advances in modeling the interaction between microphysical and chemical processes, J. Atmos. Chem., 18, 247-266, 1994.

Grell, G. A.: Prognostic evaluation of assumptions used by cumulus parameterization, Mon. Wea. Rev., 121, 764-787, 1993.

Grell, G. A. and Devenyi, D.: A generalized approach to parameterizing convection combining ensemble and data assimilation techniques, Geophys. Res. Letters, 29, 1693, doi:10.1029/2002GL015311, 2002.

Held, G. and Nachtigall, L. F.: Flood producing storms in Bauru during February 2001, in Proc XII Congresso Brasileiro de Meteorologia, SBMET, Foz de Iguaçu, 3155-3163, 2002.

Hesstvedt, E., Hov, O., and Isaksen, I. S.: Quasi-steady state approximations in air pollution modeling: comparison of two numerical schemes for oxidant prediction, Int. J. Chem. Kin., 10, 971, 1978.

Holton, J. R., Haynes, P. H., McIntyre, M. E., Douglass, A. R., Rood, R. B., and Pfister, L.: Stratosphere-Troposphere exchange, Rev. Geophys, 33, 403-439, 1995.

Jonquières, I. and Marenco, A.: Redistribution by deep convection and long-range transport of $\mathrm{CO}$ and $\mathrm{CH} 4$ emissions from the Amazon basin, as observed by the airborne campaign TROPOZ II during the wet season, J. Geophys. Res., 103, 19075-19091, 1998.

Josse B., Simon, P., and Peuch, V.-H.: Rn-222 global simulations with the multiscale CTM MOCAGE, Tellus, 56, 339-356, 2004.

Jourdain, L.: Modélisation des oxides d'azote et de l'ozone dans le modèle de circulation générale LMDzT-INCA: rôle des émissions par les éclairs et par l'aviation subsonique, PhD Thesis, Université Paris 6, 4 July 2003.

Kirchhoff, V. W. J. H., and Alvala, P. C.: Overview of an aircraft expedition into the Brazilian cerrado for the observation of atmospheric trace gases, J. Geophys. Res., 101(D19), 23 973-23 981, 1996.

Labrador, L. J., von Kuhlmann, R., and Lawrence, M.G.: Strong sensitivity of the global mean $\mathrm{OH}$ concentration and the tropospheric oxidizing efficiency to the source of $\mathrm{NO}_{\mathrm{x}}$ from lightning, Geophy. Res. Lett., 31, L06102, doi:10.1029/2003GL019229, 2004.

Logan, J. A.: An analysis of ozonesonde data for the troposphere: Recommendations for testing three-dimensional models and development of a gridded climatology for tropospheric ozone, J. Geophys. Res., 104(D23), 16 151-16170, 1999.

Madronich, S. and Flocke, S.: The role of solar radiation in atmospheric chemistry, in: Handbook of Environmental Chemistry edited by: P. Boule, Springer-Verlag, Heidelberg, 1-26, 1999.

Marenco, A., Jonquières, I., Gouget, H., and Nédélec, P.: Experimental determinations of meridional distribution and long term evolution of tropospheric ozone from large scale airborne cam- 
paigns (STRATOZ/TROPOZ) and Pic du Midi data series, Consequences on radiative forcing, Global Environmental Change, edited by: W. C. Wang and I. S. A. Isaksen, NATO ASI Ser., 32, 305-319, 1995.

Mari, C., Jacob, D. J., and Bechtold, P.: Transport and scavenging of soluble gases in a deep convective cloud, J. Geophys. Res., 105(D17), 22 255-22 268, 10.1029/2000JD900211, 2000.

Mari, C., Saüt, C., Jacob, D. J., Staudt, A., Avery, M. A., Brune, W. H., Faloona, I., Heikes, B. G., Sachse, G. W., Sandholm, S. T., Singh, H. B., and Tan, D.: On the relative role of convection, chemistry and transport over the South Pacific Convergence Zone during PEM-Tropics B: A case study, J. Geophys. Res., 107, 8232, doi:10.1029/2001JD001466, 2003.

Peuch V.-H., Amodei, M., Barthet, T., Cathala, M.-L., Josse, B., Michou, M., and Simon, P.: MOCAGE, MOdèle de Chimie Atmosphérique à Grande Echelle, In: Proceedings of Météo-France workshop on atmospheric modelling, December 1999, 33-36, 1999.

Pickering, K. E., Thompson, A. M., Dickerson, R. R., Luke, W. T., McNamara, D. P., Greenberg, J. P., and Zimmerman, P. R.: Model calculations of tropospheric ozone production potential following observed convective events, J. Geophys. Res., 95, 14 049-14 062, 1990.

Pickering, K. E., Yansen Wang, Wei-Kuo Tao, Colin Price and Müller, J.-F.: Vertical distributions of lightning $\mathrm{NO}_{\mathrm{x}}$ for use in regional and global chemical transport models, J. Geophys. Res., 103, 31 203-31 216, 1998.

Pielke, R. A., Cotton, W. R., Walko, R. L., Tremback, C.J., Lyons, W. A., Grasso, L. D., Nicholls, M. E., Moran, M. D., Wesley, D. A., Lee, T. J., and Copeland, J. H.: A comprehensive meteorological modeling system - RAMS, Meteorol. Atmos., 49, 69-91, 1992.

Poulet, D., Cautenet, S., and Aumont, B.: Simulation of the chemical impact of the bush fires emissions in Central Africa during the EXPRESSO campaign, J. Geophys. Res., In revision, 2004.

Price, C., Penner, J., and Prather, M.: $\mathrm{NO}_{\mathrm{x}}$ from lightning, 1, Global distribution based on lightning physics, , J. Geophys. Res., 102, 5929-5941, 1997.

Pundt, I., Pommereau, J.-P., Chipperfield, M. P., Van Roozendael, M., and Goutail, F.: Climatology of the stratospheric $\mathrm{BrO}$ vertical distribution by balloon-borne UV-Visible spectrometry, J. Geophys. Res., 107 (D24), doi:10.1029/2002JD002230, 2002.

Rivière, E. D., Marécal., V., Larsen, N. and Cautenet, S.: Modelling study of the impact of deep convection on the UTLS air composition, Part 2: Ozone budget in the TTL, Atmos. Chem. and Phys., acp-2005-0110, 2006.
Salzmann, M., Lawrence, M. G., Phillips, V. T. J., and Donner, L. J.: Modelling tracer transport by a cumulus ensemble, lateral boundary conditions and large-scale ascent, Atmos. Chem. Phys., 4, 1797-1811, 2004.

Taghavi, M., Cautenet, S. and Foret, G.: Simulation of ozone production in a complex circulation region using nested grids, Atmos. Chem. Phys., 4, 825-838, 2004.

Thompson, M. A., et al.: Southern hemisphere additional ozonesondes (SHADOZ) 1998-2000 tropical ozone climatology 2, Tropospheric variability and the zonal wave-one, J. Geophys. Res., 108(D2), 8241, doi:1029/2002JD002241, 2003.

Thorntorn, D. C., Bandy, A. R., Blomquist, B. W., Bradshaw, J. D., and Blake, D. R.: Vertical transport of sulfur dioxide and dimethyl sulfide in deep convection and its role in new particle formation, J. Geophys. Res., 102, 28 501-28 509, 1997.

Tulet, P., Suhre, K., Mari, C., Solmon, F. and Rosset, R.: Mixing of boundary layer and upper troposphere ozone during a deep convective event over Western Europe, Atmos. Env., 36, 44914501, 2002.

Vömel, H., Oltmans, S. J., Johnson, B. J., Hasebe, F., Shiotani, M., Fujiwara, M., Nishi, N., Agama, M., Cornejo, J., Paredes, F., and Enriquez, H.: Balloon-borne observations of water vapor and ozone in the tropical upper troposphere and lower stratosphere, J. Geophys. Res., 107(D14), doi:10.1029/2001JD000707, 2002.

Walko, R. L., Tremback, C. J., Pielke, R.A., and Cotton, W. R.: An interactive nesting algorithm for stretched grids and variable nesting ratios, J. Appl. Meteorol., 34, 994-999, 1995a.

Walko, R. L., Cotton, W. R., Meyers, M. P. and Harrington, J. Y.: New RAMS cloud microphysics parameterization, Part I: the single-moment scheme, 38, 29-62, 1995b.

Wang, Y., Tao, W. K., Pickering, K. E., Thompson, A. M., Kain, J. S., Adler, R. F., Simpson, J., Keehn, P. R., and Lai, G. S.: Mesoscale model simulations of TRACE A and Preliminary Regional Experiment for Strom-scale Operational and Reasearch Meteorology convective systems and associated tracer transport, J. Geophys. Res., 101(D19), 24 013-24 027, 1996.

Wang, C. and Prinn, R. G.: On the roles of deep convective clouds in tropospheric chemistry, J. Geophys. Res., 105, 22 269-22 297, 2000.

Willmott, C. J.: On the validation of models, Physical Geography 2, 168-194, 1981.

Yin, Y., Parker, D. J., and Carslaw, K. S.: Simulation of trace gas redistribution by convective clouds-Liquid phase processes, Atmos. Chem. Phys., 1, 19-36, 2001. 